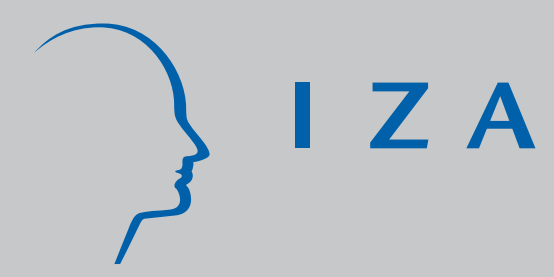

IZADP No. 1636

Racial Harassment, J ob Satisfaction and Intentions to Remain in the Military

Heather Antecol

Deborah Cobb-Clark

J une 2005 


\title{
Racial Harassment, Job Satisfaction and Intentions to Remain in the Military
}

\author{
Heather Antecol \\ Claremont McKenna College \\ and IZA Bonn \\ Deborah Cobb-Clark \\ Australian National University \\ and IZA Bonn
}

Discussion Paper No. 1636

June 2005

IZA

P.O. Box 7240

53072 Bonn

Germany

Phone: +49-228-3894-0

Fax: +49-228-3894-180

Email: iza@iza.org

Any opinions expressed here are those of the author(s) and not those of the institute. Research disseminated by IZA may include views on policy, but the institute itself takes no institutional policy positions.

The Institute for the Study of Labor (IZA) in Bonn is a local and virtual international research center and a place of communication between science, politics and business. IZA is an independent nonprofit company supported by Deutsche Post World Net. The center is associated with the University of Bonn and offers a stimulating research environment through its research networks, research support, and visitors and doctoral programs. IZA engages in (i) original and internationally competitive research in all fields of labor economics, (ii) development of policy concepts, and (iii) dissemination of research results and concepts to the interested public.

IZA Discussion Papers often represent preliminary work and are circulated to encourage discussion. Citation of such a paper should account for its provisional character. A revised version may be available directly from the author. 


\section{ABSTRACT}

\section{Racial Harassment, Job Satisfaction and Intentions to Remain in the Military*}

Our results indicate that two-thirds of active-duty military personnel report experiencing offensive racial behaviors in the previous 12 months, while approximately one in ten report threatening racial incidents or career-related discrimination. Racial harassment significantly increases job dissatisfaction irrespective of the form of harassment considered. Furthermore, threatening racial incidents and career-related discrimination heighten intentions to leave the military, though there is no significant effect of racially offensive behavior on the intended job change of active-duty personnel. Finally, our results point to the importance of accounting for unobserved individual- and job-specific heterogeneity when assessing the consequences of racial harassment. In particular, single-equation models result in estimated effects of racial harassment on job satisfaction and intended job change that are generally understated.

JEL Classification: J16, J28

Keywords: job satisfaction, racial harassment, quits, military employment

Corresponding author:

Deborah Cobb-Clark SPEAR Centre, RSSS

Australian National University

Canberra ACT, 0200

Australia

Email: deborah.cobb-clark@anu.edu.au

\footnotetext{
* We thank the Defense Manpower Data Center for providing us access to variables related to location from the confidential files of the 1996 Armed Forces Equal Opportunity Survey (AF-EOS). Many helpful comments were provided by seminar participants at RAND. None of the views expressed in this paper represent the official views of the U.S. Department of Defense and all errors remain our own.
} 


\section{Introduction}

An increase in the racial and ethnic diversity of the U.S. population has left many employers managing more heterogenous groups of workers than ever before. ${ }^{1}$ On the one hand, workplace diversity appears to facilitate greater creativity and lead to more scope for problem solving, while on the other hand, diversity can also result in greater discontent among workers. This tension has led to a large literature-across the range of social science disciplines - that seeks to investigate issues related to race and ethnicity in the workplace. ${ }^{2}$

Diversity issues are particularly salient for the U.S. military. Historically the military has been relatively integrated when compared to other social institutions and has consequently provided a key source of socioeconomic mobility for black Americans (Ellison, 1992; Moskos and Butler, 1996). The military has become even more racially and ethnically diverse over time. Between 1973 when the all-volunteer force was established, for example, and 1999 minority representation within the active-duty officer corps grew from 4.2 to 16.9 percent despite the overall downsizing of the defense forces in the late 1980s (DoD, undated, p. 92; Dansby, et. al., 2001). ${ }^{3}$ Unfortunately, this increased diversity has not come without cost. In particular, reports of racial and ethnic harassment are common in the U.S. military (Antecol and Cobb-Clark, 2004b) and the

\footnotetext{
${ }^{1}$ For example, between 1990 and 2000 the proportion of the U.S. population identified as non-Hispanic white fell from 75.6 percent to 69.1 percent. At the same time, Hispanics increased from 9.0 to 12.5 percent of the population, the proportion of Asians increased from 2.7 percent to 3.6 percent, while the proportion of blacks remained relatively steady (11.7 percent in 1990 versus 12.1 percent in 2000) (U.S. Census Bureau, 2001, Tables 1 and 4.)

${ }^{2}$ See Milliken and Martins (1996) for a review of the organizational psychology literature on the effects of workplace diversity. Lazear (1999) examines the incentives for diversity in team building, while Alesina and La Ferrara (2003) consider the relationship between ethnic diversity and economic performance generally. Finally, Hamilton, et. al., (2004) present empirical evidence on the impact of team diversity on productivity.

${ }^{3}$ Moreover, in 1999 fully 36.4 percent of all active-duty personnel were minority group members (Dansby, et. al., 2001, p. 221) and Moskos and Butler (1996) argue that the U.S. Army is the one institution in which whites are routinely supervised by blacks.
} 
U.S. military spends millions of dollars each year supporting equal opportunity practices (Edwards, 2001). The development of effective policies for managing diversity and limiting discord is vital in light of these costs and suggestions that, in the future, the military may find "the equal opportunity climate of its units is one of its primary criteria of mission effectiveness" (Knouse, 1991, pg. 386). ${ }^{4}$

Our objective is to contribute to the literature on workplace diversity by examining the consequences of racial harassment for individuals' job satisfaction and intended job change. ${ }^{5}$ To this end, we utilize data on a sample of active-duty personnel in the U.S. military captured in the Armed Forces Equal Opportunity Survey (AF-EOS) which provides us with direct information about the nature and extent of harassment individuals have faced. ${ }^{6}$ Large samples, detailed information, and the ability to identify unique military installations (workplaces) make the data especially well suited to the task at hand. Given our interest in the consequences of racial harassment, we develop a simultaneous-equation model in which harassment affects job satisfaction directly andthrough the job satisfaction equation—has indirect effects on intended quits. This specification allows the error terms to be correlated across equations and consequently accounts for the effects of any unobserved individual- and job-specific effects-related to, for example, specific military jobs or individuals' attitudes toward work-that jointly

\footnotetext{
${ }^{4}$ Note that a similar argument can be made with respect to sexual harassment and the integration of women into the U.S. military (see Antecol and Cobb-Clark, 2004a). In particular, sexual harassment has been linked to a reduction in unit cohesion and combat readiness (Rosen and Martin, 1997).

${ }^{5}$ In the analysis we will also consider harassment of Asians, Hispanics and Native Americans. Although harassment of these groups is more likely based on ethnicity rather than race, we will continue to refer to this as "racial" harassment for simplicity.

${ }^{6}$ Empirical estimates of labor market discrimination are generally derived from residual differences in aggregate outcomes once observable productivity-related characteristics have been taken into account. Omitted variables, unobserved heterogeneity, and measurement error can all confound residual-based estimates of labor market discrimination, however, leading to an increased interest in the use of direct survey data to measure discrimination (e.g., Kuhn, 1987; Hampton and Heywood, 1993; Laband and Lentz 1998; Johnson and Neumark, 1997; Antecol and Kuhn, 2000; Shields and Wheatly Price, 2002a, 2002b; Antecol and Cobb-Clark, 2004a; 2004b).
} 
determine more than one of our outcomes of interest. Explicitly accounting for this endogeneity is important in producing consistent estimates of the consequences of racial harassment.

Studying the effect of racial harassment on job satisfaction is of interest because job satisfaction itself is a measure of overall well-being (Clark, 1996; 1997). ${ }^{7}$ Additionally, job satisfaction is an important predictor of individual behavior. The psychology literature, for example, provides evidence that low job satisfaction is correlated with increased absenteeism (Clegg, 1983), lower worker productivity (Mangione and Quinn, 1975), and increased incidence of mental and physical health problems (Locke, 1976). More importantly for our purposes here, job satisfaction is also related to both intentions to quit (Shields and Wheatley Price, 2002b; Shields and Ward, 2001; Laband and Lentz, 1998; Gordon and Denisi, 1995) and actual quit behavior (Kristensen and Westergård-Neilsen, 2004; Clark, 2001; Bertrand and Mullainathan, 2001; Clark, et al., 1998; Freeman, 1978) with estimates derived from panel data demonstrating that the causality runs from job satisfaction to future quitting behavior. In light of the need to recruit and retain high-quality personnel (Hoesek and Sharp, 2001), the costs of racial harassment are likely to be substantial if harassment results in men and women failing to enlist or once enlisted, choosing to end their military careers.

Moreover, studying the effect of racial harassment on job satisfaction and intended job change is helpful in expanding our understanding of the consequences of

\footnotetext{
${ }^{7}$ Although economists first considered the issue of job satisfaction more than thirty years ago (Hamermesh, 1977; Freeman, 1978), in subsequent years the study of job satisfaction was mainly the purview of psychologists and sociologists. In recent years many authors have noted a surge of interest on the part of economists in studying subjective outcomes generally (Clark, 1996) and job satisfaction in particular (Heywood and Wei, 2001; Shields and Ward, 2001). See Clark, (1996); Clark and Oswald, (1996); Heywood and Wei, (2001); and Shields and Ward, (2001) for reviews of the economics literature on job satisfaction.
} 
labor market discrimination more generally. Racial harassment is a particularly blatant form of racism that is discriminatory by its very nature (see Shields and Wheatley Price, 2002a on this point). Despite a vast literature on the effects of labor market discrimination on the aggregate wages of different groups, little attention has been paid to the consequences of discrimination for other outcomes of interest and even less attention has been directed towards the effects of racial harassment per se (see McClelland and Hunter, 1992). ${ }^{8}$ This is unfortunate since psychologists studying prejudice argue that discrimination is often motivated by preferential treatment of in-group members rather than direct hostility towards out-group members (Brewer, 1999), suggesting that the forces driving discrimination and harassment per se are likely to differ. ${ }^{9}$

Our results indicate that two-thirds of active-duty military personnel report experiencing offensive racial behaviors in the previous 12 months, while approximately one in ten report threatening racial incidents or career-related discrimination. Racial harassment significantly increases job dissatisfaction irrespective of the form of harassment considered. Furthermore, threatening racial incidents and career-related discrimination heighten intentions to leave the military, though there is no significant effect of racially offensive behavior on the intended job change of active-duty personnel. Finally, our results point to the importance of accounting for unobserved individual- and job-specific heterogeneity when assessing the consequences of racial harassment. In

\footnotetext{
${ }^{8}$ Exceptions include Shields and Wheatley Price (2002b) who examine the effect of racial and ethnic harassment on both job dissatisfaction and the intention to leave the British nursing profession. Additionally, Laband and Lentz (1998) and Antecol and Cobb-Clark (2004a) study the effect of sexual harassment on the job satisfaction and intended job change of female lawyers and female military personnel, respectively.

${ }^{9}$ Consistent with this, our previous work indicates that institutional factors related to the equal opportunity climate and demographic composition of a military installation have differential effects on the incidence of career-related racial discrimination on the one hand and offensive and threatening racial harassment on the other (Antecol and Cobb-Clark, 2004b).
} 
particular, single-equation models result in estimated effects of racial harassment on job satisfaction and intended job change that are generally understated.

The next section provides the details of the data used in the analysis. We describe our estimation strategy in Section 3, while our results are discussed in Section 4. Conclusions follow in Section 5.

\section{The Armed Forces Equal Opportunity Survey}

We use data drawn from the public-use 1996 U.S. Armed Forces Equal Opportunity Survey (AF-EOS) combined with a randomized variable extracted from the confidential file that allows us to identify separate military installations. These data are uniquely suited to the analysis at hand. The public-use file provides us with detailed information on perceived racial harassment, job satisfaction and intentions to remain in the military, as well as demographic and human capital characteristics. Additionally, the public-use AF-EOS contains information about the equal opportunity climate, as well as social prescriptions regarding inter-racial interactions. The ability to identify unique military installations is extremely important for our purposes as it allows us to construct installation-specific measures of these organizational factors..$^{10}$

The data generalize to personnel in the Army, Navy, Marine Corps, Air Force, and Coast Guard with at least six months of active-duty service who are below the rank of admiral or general. A non-proportional stratified random sample of active-duty personnel was drawn from the Defense Manpower Data Center's (DMDC's) April 1996

\footnotetext{
${ }^{10}$ As Manski (1993) notes, specifying the reference group is a necessary first step in studying the effects of social groups. Military installations are a particularly useful measure of reference groups in our case because installations reflect geographically separate groups of individuals who live and work together and whose day-to-day experiences are ultimately under the command of a single individual. In particular, DoD directives make equal opportunity a commander's responsibility (Dansby and Landis, 2001).
} 
Active-duty Master File (ADMF). Data were stratified on the basis of service, location, pay level, and race/ethnicity. Minority groups were oversampled to ensure adequate numbers of minorities were available for analysis. Questionnaires were mailed to sample members between September of 1996 and January of 1997. From an initial eligible sample of 73,496 individuals $^{11}$, usable questionnaires were returned from 39,855 individuals for an overall response rate of 52.7 percent (Elig et. al. 1997; Wheeless et. al. 1997). ${ }^{12}$

We restrict our analysis to individuals with non-missing military installation codes because these codes are needed to construct our measures of equal opportunity climate and social prescriptions regarding inter-racial interactions (see Section 3 below). Unfortunately, installation codes are not generally available for overseas personnel and members of the Coast Guard and so these individuals have also been excluded from the sample. ${ }^{13}$ Moreover, we only consider installations for which we have a sample of at least 10 active-duty members in order to have sufficient precision for our installationlevel measures. ${ }^{14}$ These restrictions produce a final sample of 5,142, 4,253, 4,802, 3,682, and 1,305 white, black, Hispanic, Asian, and Native American active-duty personnel, respectively, with non-missing values for the key variables of interest.

\footnotetext{
${ }^{11}$ Although the initial non-proportional stratified random sample consisted of 76,754 active-duty personnel, 3,258 of them were found to be ineligible for the target population because they had left the military service (Elig et. al. 1997; Wheeless et. al. 1997).

${ }^{12}$ A unique feature of the AF-EOS data is that it contains basic demographic information for both respondents and non-respondents. Using this data, we find that while whites and Asians were disproportionately likely to respond to the survey, blacks are under-represented among respondents. Moreover, respondents are less likely to be in the Marines and more likely to be in the Air Force. These differences - while significant - are generally minor suggesting that the characteristics of the two groups are much the same.

${ }^{13}$ Approximately 40 (70) percent of overseas personnel (members of the Coast Guard serving in the United States) have missing installation codes, while roughly 13, 6, 4, and 4 percent of members of the Army, Navy, Marine Corps, and Air Force serving in the United States, respectively, have missing installation codes.

${ }^{14}$ Similar results are found if we consider only those installations with at least 50 active-duty members and are available upon request.
} 
Personnel in the sample were asked which of 31 separate racial harassing incidents - initiated by another military member or a Department of Defense civilianthey had experienced in the previous 12 months. ${ }^{15}$ These incidents range from being subjected to offensive racist remarks and being told racist jokes, to being evaluated unfairly or being physically assaulted because of race. Following Scarville et. al. (1997), we combine the responses to the 31 separate items in the 1996 AF-EOS into three broad categories: 1) offensive encounters, 2) threatening encounters, and 3) career-related incidents. While the latter essentially measures racial discrimination, the former two are more sensibly thought of as racial harassment per se. ${ }^{16}$ For ease of exposition, however, we shall refer to all three measures collectively as "harassment". ${ }^{17}$

Table 1 (column 1) presents the mean incidence (and standard deviation) of each type of harassment by racial group membership. Overall, offensive encounters are the most frequently reported form of racially harassing behavior (65.1 percent), with careerrelated (12.8 percent) and threatening incidents (9.0 percent) occurring less frequently. This general pattern holds within racial groups, although there is substantial diversity in perceived harassment across groups. No racial group uniformly reports a higher incidence of every type of harassing behavior. In particular, reports of offensive encounters are highest among Hispanics (77.5 percent), while reports of threatening

\footnotetext{
${ }^{15}$ Personnel were also asked about a range of incidents of racial harassment initiated by civilians in the local community surrounding the military base. Community-based harassment is beyond the scope of this paper and is a topic of current research.

${ }^{16}$ Scarville et. al. (1997) used a principal component analysis with orthogonal rotation to assign each of the 31 types of encounters into six broad categories. As four of their categories (assignment/career, evaluation, punishment, and training/test scores) all pertain to racial discrimination with respect to aspects of ones military career, we have combined these four categories into one broad category which we label "careerrelated". The remaining categories are identical to those considered by Scarville et. al. (1997). See Appendix Table 1 for a detailed list of the specific behaviors that make up each type of racial harassment.

${ }^{17}$ Harassment is measured by asking individuals directly about events or situations that they have encountered and is perhaps better thought of as "perceived" rather than "actual" harassment. However, even if harassment could be objectively measured, it is likely that it is perceptions of harassment that are important in understanding job satisfaction and intended job change.
} 
encounters and career-related incidents are highest among Native Americans (15.7 percent) and among blacks (28.7 percent), respectively. White personnel are less likely to report all types of harassing behavior than are their non-white counterparts, though the majority (60.9 percent) of white personnel also report being subjected to racially offensive encounters. This rate is considerably higher than the incidence of racial harassment reported by white British nurses, although harassment levels among nonwhite military personnel and British nurses are often quite similar (see Shields and Wheatly Price, 2002a).

\section{Table 1 Here}

In addition to asking active-duty personnel about the incidence of racially harassing behavior in the military, the AF-EOS survey also collected information about how satisfied individuals were with certain aspects of military life. Specifically, individuals were asked the following questions. First, how satisfied are you with your job as a whole? Second, suppose that you need to decide whether to remain in the military. Assuming you could remain, how likely is it that you choose to do so? ${ }^{18} \mathrm{We}$ consider the following measures of job satisfaction and intended job change in the military. "Dissatisfied" equals one for individuals reporting that they are either dissatisfied or very dissatisfied with their job as a whole and zero otherwise and "Quit" equals one for individuals reporting that they are either unlikely or very unlikely to remain in the military.

Table 1 also reports the incidence of job dissatisfaction and intended job change by race and harassment experience. Overall, 16.9 percent of military personnel report

\footnotetext{
${ }^{18}$ Possible responses to the first question include: very dissatisfied, dissatisfied, neither, satisfied, and very satisfied. Possible responses to the second question are: very unlikely, unlikely, neither, likely, and very likely.
} 
dissatisfaction with their military jobs and 26.7 percent report intending to leave the military. In general, non-white personnel have levels of job dissatisfaction similar to whites, although intended job change is generally somewhat lower among minority personnel. For example, overall 27.6 percent of white personnel report intending to end their military career which is the same as the rate of intended job change amongst Native Americans (27.5), but slightly higher than that of blacks (24.8 percent), Hispanics (25.0 percent), and Asians (20.0 percent). These results are consistent with previous research on civilian workers suggesting that — despite being in generally less attractive jobsgroups such as blacks and women often exhibit similar or higher levels of job satisfaction, a finding which has been attributed to lower expectations (Bartel, 1981; Clark, 1997).

Not surprisingly, job dissatisfaction and intentions to leave the military are higher amongst those reporting some form of racial harassment irrespective of race. ${ }^{19}$ Dissatisfaction and intentions to leave the military are particularly high amongst those who have experienced racially threatening incidents and career-related discrimination. For example, overall 18.1 (24.8) percent of black personnel report dissatisfaction with their military career (intending to leave the military) compared to 31.3 (37.8) and 27.0 (35.6) percent for black personnel reporting racially threatening incidents and careerrelated discrimination, respectively.

\footnotetext{
${ }^{19}$ Similarly, regardless of race, intentions to leave the military are higher amongst those reporting dissatisfaction with military employment. In particular, white, Hispanic and Asian personnel are roughly twice as likely to report intending to leave the military if they are dissatisfied with military employment while black and Native American personnel are approximately one and a half times more likely to report intended job change if they are dissatisfied with military employment.
} 


\section{The Estimation Model}

Our interest is in assessing the consequences of racial harassment for military personnel's dissatisfaction with and intentions to leave military employment. One obvious strategy for addressing this issue would be to incorporate measures of harassment directly into a job satisfaction and/or an intended job change equation. Although this approach has been used previously in the harassment literature (see for example, Laband and Lentz, 1998; Shields and Wheatly Price, 2002b; Antecol and Cobb-Clark, 2004a), it is possible that unobservable individual- or job-specific characteristics may jointly determine both perceived harassment and the other outcomes of interest. Failure to account for this endogeneity would lead the single-equation estimates of the effect of harassment on job satisfaction and intended job change to be biased. ${ }^{20}$ Consequently, we develop a simultaneous-equations model in which we allow the error terms to be correlated across equations in order to take account of any unobserved heterogeneity.

In our model, perceived racial harassment directly affects job dissatisfaction and - through the job dissatisfaction equation-has indirect effects on the intention to leave the military equation. We assume that harassment has no direct effect on intended job change beyond its effect in reducing job satisfaction. This specification seems to us to be both intuitively appealing and consistent with the empirical literature demonstrating the close link between job satisfaction on the one hand and both intended and actual quits on the other. ${ }^{21}$ The cross-sectional nature of our data precludes assessing the effect of

\footnotetext{
${ }^{20}$ Antecol and Cobb-Clark (2004a) find that endogeneity leads single-equation estimates of the effect of sexual harassment on job satisfaction and intended quits to be overstated. At the same time, Shields and Wheatley Price (2002b) conclude that although significant correlations exist between the error terms in their racial harassment, job satisfaction, and intended job change equations, their results based on singleequation models are generally robust to endogeneity concerns.

${ }^{21}$ To investigate this identifying assumption, we reformulated the estimation model allowing harassment to have both direct and indirect effects on intended job change. The direct effect of harassment on intended
} 
racial harassment and subsequent job dissatisfaction on actual quitting behavior. Consequently, we follow others in this literature and focus instead on individuals' intentions regarding their future employment decisions (see Shields and Wheatley Price, 2002b; Shields and Ward, 2001; Laband and Lentz, 1998; Gordon and Denisi, 1995). ${ }^{22}$ Given this, we adopt the following model:

$$
\begin{array}{ll}
H_{i j}^{*} & =\quad X_{i j} \beta_{1}+J_{i j} \beta_{2}+I_{i j} \beta_{3}+\varepsilon_{i j}^{H} \\
D_{i j}^{*}=H_{i j} \delta_{0}+X_{i j} \delta_{1}+J_{i j} \delta_{2}+R_{i j} \delta_{3}+\varepsilon_{i j}^{J S} \\
Q_{i j}^{*}=D_{i j} \lambda_{0}+X_{i j} \lambda_{1}+M_{i j} \lambda_{3}+\varepsilon_{i j}^{Q}
\end{array}
$$

where $i$ indexes individuals, $j$ indexes military installations, $H_{i j}^{*}$ is the propensity to perceive racial harassment, $D_{i j}^{*}$ is the propensity to be dissatisfied with ones job, $Q_{i j}^{*}$ is the propensity to report intending to leave the military and $H_{i j}, D_{i j}$, and $Q_{i j}$ are the observed harassment, job dissatisfaction, intended job change outcomes (defined below), respectively. Furthermore, $X_{i j}$ is a vector-common to all equations - of background characteristics (gender, education, years of active-duty service, officer status and service), installation-specific measures of diversity and overall race relations ${ }^{23}$, and a constant.

quits was generally insignificant in our specifications and the overall results were substantially the same. (These results are not presented here, but are available upon request.)

${ }^{22}$ A large psychology literature documents the close link between workers' stated intentions to quit and future job change. See Steel and Orvalle (1984) for a review.

${ }^{23}$ In calculating these installation-specific measures we first created two indicator variables as follows: 1) white - equaling one if the respondent is white; and 2) positive race relations-equaling one if the respondent to a (very) large extent believes race relations are good at his or her installation/ship. In all other cases - including item non-response - these two indicator variables are coded as zero. Weighted, installation-specific averages are then calculated and assigned to each individual. 
Additionally, both the harassment and job dissatisfaction equations control for the extent to which individuals engage in inter-racial interactions in their work environment $\left(J_{i j}\right) .^{24}$

Previous research indicates that the incidence of sexual and racial harassment is related to the extent to which the organization is successful in creating a climate in which harassment is not tolerated (Williams, et al. 1999; Shields and Wheatly Price, 2002a; Antecol and Cobb-Clark, 2004a; 2004b), while social prescriptions constraining interracial interactions are associated with significantly more offensive racial encounters and career-related racial discrimination (Antecol and Cobb-Clark, 2004b). Consequently, the propensity to report experiencing racial harassment is assumed to be a function of $I_{i j}$ which captures a respondent's awareness of racial harassment issues generally, ${ }^{25}$ as well as the equal opportunity climate and social prescriptions regarding inter-racial interactions at the individual's installation. Specifically, we control for equal opportunity climate through 1) the rate of racial confrontation; 2) the perceived probability of repercussions for reporting harassment; 3) the availability of harassment hotlines; and 4) the availability of formal complaint channels. ${ }^{26}$

\footnotetext{
${ }^{24}$ This is captured by two measures: (1) whether the respondent is in a work environment where members of their race are uncommon; and (2) whether the race of the respondent's supervisor is different from his or her own.

${ }^{25}$ Awareness of racial harassment programs is captured through three dummy variables indicating whether the respondent 1) had participated in a racial harassment training program; 2) believed the installation had a racial harassment hotline; and 3) believed that the installation had a formal racial harassment complaint channel.

${ }^{26}$ In calculating these measures we first created four indicator variables using information about an individual's experiences on his or her installation/ship as follows: 1) racial confrontation - equaling one if the respondent either saw (or experienced) racial confrontation in the past 12 months; 2) repercussionsequaling one if the respondent to a (very) large extent feels free to report racial harassment without the fear of repercussions; 3 ) hotlines - equaling one if the respondent indicates the existence of a hotline for racial harassment; and 4) formal complaint channels - equaling one if the respondent indicates the existence of a formal racial harassment complaint channel. In all other cases - including item non-response - these four indicator variables are coded as zero. Weighted, installation-specific averages are then calculated and assigned to each individual.
} 
Moreover, we control for social prescriptions governing how different racial groups should interact with each other by creating an installation-level index based on information in the AF-EOS data. In particular, respondents reported the extent to which: 1) they felt pressure from service members belonging to their own racial group not to socialize with members of other racial groups; (2) people feel free to sit wherever they choose in the dining halls regardless of race; (3) people feel free to use any recreation facilities regardless of race; (4) members of a racial group are treated as if they are "trouble" when they get together; and (5) personnel prefer to socialize with members of their own racial group when they are off duty. Higher values of the index indicate fewer constraints on inter-racial interactions. The installation level index is then calculated by assigning to each individual the weighted average of the aggregate social prescriptions index of his or her installation. ${ }^{27}$

Following Clark and Oswald (1996) we allow job satisfaction to depend on respondents' relative outside opportunities. While the previous literature has generally modeled relative opportunities in terms of comparison income (see, for example, Hamermesh, 1977; Lévy-Garboua and Montmarquette, 1996; Clark and Oswald, 1996; Clark 1996, 1997; Heywood and Wei, 2001; Shields and Wheatley Price, 2002b), this is problematic in our case because it is unclear that our data provide sufficient detail about the skills, experience, training, etc. of our sample of active-duty personnel to allow us to estimate the wage that each would command in the civilian labor force. Furthermore, a significant component of compensation in the military takes the form of difficult-to-

\footnotetext{
${ }^{27}$ Specifically, each question was answered on a 1 (not at all) to 5 (to a very large extent) scale. We rescaled (1), (4) and (5) in the opposite direction so that higher values reflect fewer constraints on interracial interactions. We then create an aggregate index ranging from 5 to 25 for each respondent by adding up the individual's responses to each of the five questions. If the respondent did not answer all 5 questions, then for the question(s) they missed they were given their mean response from the question(s) they did answer.
} 
value, often non-taxable, in-kind benefits such as family housing, housing allowances, medical and dental, child care, professional training, commissaries, etc. (Melese, et. al., 1992; Kilburn, et. al., 2001), making simple comparisons of relative civilian/military monetary income difficult. Instead, we include in the job dissatisfaction equation direct information about respondents' perceptions of the relative civilian/military opportunities for individuals of their race with respect to promotion, pay and benefits, fair performance evaluation, and acquiring education and training $\left(R_{i j}\right)$. Finally, intentions to leave the military are assumed to depend on individuals' family situation (marital status and the presence of dependent children) and on individuals' views about relative civilian/military life generally $\left(M_{i j}\right)^{28}$

Given the framework discussed above we estimate a trivariate probit model as follows: $:^{29}$

$$
\begin{aligned}
& H_{i j}=1\left(H_{i j}^{*}>0\right)=Z_{i j}^{H} \beta+\varepsilon_{i j}^{H} \\
& D_{i j}=1\left(D_{i j}^{*}>0\right)=Z_{i j}^{D} \delta+\varepsilon_{i j}^{D} \\
& Q_{i j}=1\left(Q_{i j}^{*}>0\right)=Z_{i j}^{Q} \lambda+\varepsilon_{i j}^{Q}
\end{aligned}
$$

where

\footnotetext{
${ }^{28}$ Specifically, respondent's were asked with respect to 1) promotions opportunities, 2) pay and benefits, 3) fair performance evaluations, 4) education and training opportunities, 5) quality of life and 6) chance to show pride in yourself: "Would you say that opportunities/conditions for people of your racial/ethnic group are better in the military, better in civilian employment, or that there isn't any difference?" These indicator variables are coded as one if the respondent said civilian opportunities are better, and in all other casesincluding item non-response- these variables are coded as zero. $R_{i j}$ comprises the first four, while $M_{i j}$ comprises the second two.

${ }^{29}$ All estimation is preformed in STATA 8 using a trivariate probit estimation routine developed by Cappellari and Jenkins (2003). This routine is based on the GHK smooth recursive simulator which has been found to be quite accurate and is often used in computing functions involving multivariate normal integrals (see Greene, 1997, pp. 196-197). The square root of the number of observations is used to determine the number of draws used by the trivariate probit estimation routine.
} 


$$
\begin{aligned}
& Z_{i j}^{H}=\left(X_{i j}, J_{i j}, I_{i j}\right) \\
& Z_{i j}^{D}=\left(H_{i j}, X_{i j}, J_{i j}, R_{i j}\right) \\
& Z_{i j}^{Q}=\left(D_{i j}, X_{i j}, M_{i j}\right)
\end{aligned} \text { and }\left(\begin{array}{c}
\varepsilon_{i j}^{H} \\
\varepsilon_{i j}^{D} \\
\varepsilon_{i j}^{Q}
\end{array}\right) \sim N(0, \Sigma)
$$

The model is identified through the exclusion of $J_{i j}$ from the job change equation and the inclusion of $I_{i j}$ in the harassment equation, $R_{i j}$ in the job dissatisfaction equation, and $M_{i j}$ in the job change equation. Furthermore, for identification purposes the variances of the error terms are normalized to $1 .^{30}$

Estimation is conducted first by pooling across racial/ethnic groups and including a series of racial/ethnic dummy variables in $X_{i j}$. This allows us to estimate the aggregate impact of racial group membership. We then estimate equation (2) separately by racial groups. This is consistent with our previous work demonstrating that racial group membership is not sufficient to capture the relationship between racial identity and perceived racial harassment (Antecol and Cobb-Clark, 2004b). Although race clearly matters, there is also significant diversity in the harassment experiences of individuals of the same race with diverging organizational, cultural or social experiences. Estimating the model separately for each racial group allows us to take these effects into account.

\footnotetext{
30 This estimation framework also implicitly assumes that military personnel who are neither satisfied/dissatisfied (neither likely to remain/quit) are the same as military personnel who are satisfied (likely to remain). To investigate this, we re-estimate equation (2) replacing "Dissatisfied" with "Satisfied" (equaling one for individuals reporting that they are (very) satisfied with their job as a whole) and "Quit" with "Stay" (equaling one for individuals reporting that they are (very) likely to remain in military employment). We also re-estimate equation (2) replacing dissatisfied with satisfied but leaving intentions to leave military employment. In both cases, the results did not substantially differ from those presented in the paper. Additional results are available upon request.
} 


\section{Racial Harassment, Job Satisfaction and Intentions to Quit}

We begin by considering the determinants of racial harassment from the trivariate probit estimation (equation 2) in Table 2. Following that, we discuss the consequences of racial harassment for overall job dissatisfaction and intentions to leave military employment. Although these latter results are based on the same trivariate probit estimation underlying Table 2 , for convenience we present them separately in Table 3 . For ease of interpretation, we report marginal effects (evaluated at means) and standard errors (calculated using the delta method) in Tables 2 and $3 .^{31}$

\subsection{The Determinants of Racial Harassment}

Both blacks and Hispanics are significantly more likely to report experiencing racially offensive behavior and career-related discrimination than are their white colleagues (see Table 2). This racial gap is particularly large for career-related discrimination with Hispanics reporting approximately 50 percent more and blacks reporting approximately twice as much career-related discrimination. ${ }^{32}$ There are no significant racial differences in reports of threatening racial incidents once other characteristics are controlled for, while Asians are significantly less likely to report experiencing offensive racial behavior.

\section{Table 2 Here}

Military personnel who report an awareness of racial harassment issues are often less likely to report experiencing racial harassment. This is particularly true for minority personnel. Specifically, participation in racial harassment training is associated with a

\footnotetext{
${ }^{31}$ The marginal effects (evaluated at the mean) are calculated using a continuous approximation for continuous variables and changes from 0 to 1 for discrete variables considering each respective equation separately.

${ }^{32}$ These are based on the overall sample averages (see Table 1).
} 
significantly lower probability of reporting career-related racial discrimination irrespective of minority group membership. ${ }^{33}$ Similarly, respondents are often significantly less likely to report racial harassment if they believe that their installation has a racial harassment hotline or formal complaint channels. Black personnel, for example, are 5.9 percentage points less likely to report offensive racial behavior and 7.2 percentage points less likely to report career-related discrimination if they respond that their installation has a racial harassment hotline. Interestingly, an individual's propensity to report racial harassment is generally not related to the proportion of his or her colleagues also reporting that the installation has a racial harassment hotline and formal complaint channel. This suggests that it is the personal awareness of racial harassment issues rather than these specific institutional factors that are most closely aligned with individuals' perceptions of racial harassment. ${ }^{34}$

Other aspects of installations do affect individuals' perceptions of racial harassment. Overall, higher levels of racial confrontation are associated with increased probabilities of both offensive and threatening encounters (as might be expected), but not career-related discrimination. ${ }^{35}$ Moreover, social prescriptions regarding inter-racial interactions lead to consistently higher rates of racially offensive behavior and career-

\footnotetext{
${ }^{33}$ This is consistent with previous evidence on the effects of sexual harassment training on reports of sexual harassment amongst female military personnel (Antecol and Cobb-Clark, 2004a).

${ }^{34}$ In contrast, previous research examining sexual harassment in the federal government indicates that widespread training within the agency has an effect over and above that attributable to the individual's training history. In particular, employees in agencies with higher overall training rates had more expansive definitions of the behaviors constituting sexual harassment irrespective of whether or not they had personally attended training (Antecol and Cobb-Clark, 2003).

${ }^{35}$ Interestingly, the rate of racial confrontation increases the probability of offensive racial behaviors for all groups (though the effect is not significant for Hispanics and Asians at standard levels), while with respect to threatening racial incidents this appears to be largely a white phenomenon.
} 
related discrimination for military personnel overall. ${ }^{36}$ At the same time, our measures of social prescriptions are generally unrelated to reports of threatening racial incidents.

Finally, we consider the effects of workgroup demographics $\left(J_{i j}\right)$ on individuals' perceptions of racial harassment. Irrespective of race, personnel who work in groups where their own race is uncommon are generally more likely to report all forms of racial harassment. White personnel, for example, are 17.3, 5.1, and 10.5 percentage points more likely to report offensive racial behavior, threatening racial incidents, and careerrelated discrimination, respectively, if their workmates are generally of a different race. The race of ones supervisor is generally less important in predicting perceived racial harassment. However, white, black and Asian personnel report more career-related discrimination when their supervisor is of a different race, while white personnel are also somewhat more likely to report threatening racial incidents.

\subsection{The Consequences of Racial Harassment: Job Satisfaction and Intentions to Quit}

To place our results in context, we focus first on the examining some of the key determinants - in particular, inter-racial interactions in the workplace, relative civilian/military opportunities, and family demographics—of job dissatisfaction and intentions to leave the military. We then consider the consequences of racial harassment on job dissatisfaction and intended job changes.

\footnotetext{
${ }^{36}$ These overall results hide some important racial differences. Specifically, social prescriptions regarding inter-racial interactions lead to significantly higher rates of perceived offensive behaviors (career-related discrimination) only for white (white and black) personnel.
} 


\subsubsection{Key Determinants of Job Dissatisfaction and Intentions to Quit:}

Estimated results for the key determinants in the job dissatisfaction and intended quit equations are substantially the same irrespective of the underlying measure of racial harassment considered (see Table 3). Given this, we focus our attention on the results arising from the model including offensive racial behavior.

\section{Table 3 Here}

There are several things to note. First, it is generally the case that military personnel who work in groups where their own race is uncommon or who have a supervisor of a different race do not report significantly different levels of job dissatisfaction. Thus, any impact of inter-racial interactions at work on job dissatisfaction occurs only indirectly by increasing the propensity to report being harassed. Secondly, better civilian opportunities with respect to promotion, fair performance evaluations, and education and training increase military personnel's job dissatisfaction by $4.9,4.4$, and 11.5 percentage points, respectively (see the first column of panel 1 in Table 3). At the same time, perceptions of relative civilian/military pay do not significantly affect job satisfaction. ${ }^{37}$ This is in contrast to other evidence that indicates that, while not necessarily the most important factor, satisfaction with pay is nonetheless quite important in determining the overall job satisfaction of civilian workers (Kristensen and Westergård-Neilsen, 2004; Clark, 2001).

Thirdly, military personnel who are married and who have dependent children are less likely to report intending to leave the military. This overall result is largely driven

\footnotetext{
${ }^{37}$ Interestingly, the overall effect of civilian opportunities with respect to promotion, pay and benefits, fair performance evaluation, and education and training on job dissatisfaction tend to hold for all racial groups (although at times they are insignificant), with the exception of Asians and Native Americans with respect to pay and benefits.
} 
by the responses of white and Hispanic personnel. For example, Hispanic personnel who are married (have dependent children present) are 9.3 (7.0) percentage points less likely to intend to leave the military than their single (childless) counterparts. These results are not surprising given that the value of military benefits is substantially higher for personnel with dependents (Kilburn, et al., 2001). ${ }^{38}$ Finally, military personnel are generally more likely to intend to leave the military when civilian opportunities with respect to quality of life and the potential to show pride in oneself are perceived to be better.

\subsubsection{The Effects of Racial Harassment and Job Dissatisfaction:}

We now turn to the consequences of racial harassment for job dissatisfaction and intentions to leave the military. Racial harassment affects job dissatisfaction directly and has indirect effects - through increased job dissatisfaction - on intentions to leave the military. We are interested in the magnitude of both effects. The effect of racial harassment on job dissatisfaction is given by

$$
P\left(D_{i j}=1 \mid H_{i j}=1\right)-P\left(D_{i j}=1 \mid H_{i j}=0\right)
$$

and these results are reported in the first row of panel 1 in Table 3. As harassment has only direct effects on job dissatisfaction this can be easily calculated as described in Section 4.1. ${ }^{39}$ The effect of job dissatisfaction on intended job change can be calculated similarly and these results are reported in the second row of panel 2 of Table 3. At the same time, racial harassment has only indirect effects on intentions to quit and so we

\footnotetext{
${ }^{38}$ Specifically, in addition to their basic pay, military personnel receive additional payments that depend in part on the number of dependents they have. Housing allowances and the value of medical benefits also explicitly vary with the number of dependents (Kilburn, et al., 2001). Many components of military pay and benefits are nontaxable.

${ }^{39}$ Standard errors are evaluated using the delta method.
} 
calculate the conditional probability of intending to leave the military when racial harassment does and does not occur. In other words, we calculate

$$
\begin{aligned}
P\left(Q_{i j}=1 \mid H_{i j}=1\right)- & P\left(Q_{i j}=1 \mid H_{i j}=0\right)= \\
& {\left[\frac{P\left(Q_{i j}=1, D_{i j}=0, H_{i j}=1\right)}{P\left(H_{i j}=1\right)}+\frac{P\left(Q_{i j}=1, D_{i j}=1, H_{i j}=1\right)}{P\left(H_{i j}=1\right)}\right]-} \\
& {\left[\frac{P\left(Q_{i j}=1, D_{i j}=0, H_{i j}=0\right)}{P\left(H_{i j}=0\right)}+\frac{P\left(Q_{i j}=1, D_{i j}=1, H_{i j}=0\right)}{P\left(H_{i j}=0\right)}\right] }
\end{aligned}
$$

and these results are reported in the first row of panel 2 in Table $3 .^{40}$

Racial harassment leads to increased job dissatisfaction. Overall, military personnel are $30.7,42.4$, and 42.2 percentage points more likely to be dissatisfied with their jobs if they experience offensive racial behaviors, threatening racial behaviors, or career-related discrimination, respectively (see Table 3). Perhaps surprisingly, the effect of racially harassing behaviors on job dissatisfaction does not differ much by race. ${ }^{41}$ Reported threatening encounters and career-related discrimination have particularly large effects, roughly tripling the rate of job dissatisfaction. Moreover, military personnel are overall more than twice as likely to intend to leave the military if they are dissatisfied with their military jobs. This link between job dissatisfaction and intended job change is

\footnotetext{
${ }^{40}$ Unlike the previous case, which relies only on the univariate cumulative standard normal distribution, this result also necessitates the use of the trivariate cumulative normal distribution. We calculated standard errors by using a Cholesky decomposition of $\Sigma$ (including the estimated correlations) to obtain $p^{\prime}$. Using $\kappa=\hat{\varphi}+p^{\prime} \eta_{i j}$ where $\hat{\varphi}=\left(\hat{\beta}, \hat{\gamma}, \hat{\delta}, \hat{\rho}_{12}, \hat{\rho}_{13}, \hat{\rho}_{23}\right)$ we randomly sampled $\eta_{i j}(\mathrm{~N}=1000)$ from a standard normal distribution and recalculated the marginal effect using alternative values of $\kappa$ in equation (5). Standard errors are based on the distribution of these results.

${ }^{41}$ The main exceptions are (1) the effect of offensive racial harassment on job dissatisfaction is smaller for Asian and Hispanic personnel than for their white, black and Native American counterparts; (2) the effect of racial harassment on job dissatisfaction-irrespective of the harassment measure - is larger for Native American personnel than for other military personnel; (3) the effect of threatening racial harassment on job dissatisfaction is smaller for white personnel than for their minority counterparts; and (4) the effect of career-related discrimination is larger for Asian and Native American personnel than for other military personnel.
} 
generally strongest for black and Asian personnel and weakest (and often insignificant) for Hispanic and Native American personnel. Effects for white personnel lie in the middle of the range.

By increasing job dissatisfaction, racial harassment also has indirect effects on personnel's intentions to leave military employment. Overall, threatening racial encounters increase intended job change by 7.6 percentage points, while career-related discrimination leads to an increased propensity to intend to quit of 7.8 percentage points. Thus, these forms of racial harassment have a substantial effect on individual's future career plans, increasing the rate of intended job change by roughly 30 percent. At the same time, offensive racial encounters have no significant effect on military personnel's intentions to leave the military. ${ }^{42}$

\subsection{The Issue of Endogeneity: Single-Equation Results}

Our results provide strong evidence that accounting for the potential endogeneity resulting from unobservable individual- and job-specific characteristics associated with reporting harassment, job dissatisfaction and intended job change is quite important. We generally find a negative and significant correlation between the error terms of the racial harassment and job dissatisfaction equations (see Appendix Table 3) and in all specifications, likelihood ratio tests reject at the one percent level the hypothesis that the estimated correlations in the error terms across equations are zero. This result suggests that unobservable factors simultaneously lead reports of racial harassment to be higher and job dissatisfaction to be lower. This might indicate, for example, that jobs with more

\footnotetext{
${ }^{42}$ While these overall results are generally consistent across racial groups, the effects of threatening encounters and career-related discrimination are statistically insignificant at conventional levels for some racial groups.
} 
interracial interactions (where harassment might be higher) are also jobs that are more inherently satisfying. Moreover, we often find a negative and significant correlation between the error terms of the job dissatisfaction and intended quits equations. At the same time, we generally do not find a significant correlation between the error terms of the racial harassment and intended quits equations. These results are consistent with Shields and Wheatley Price (2002b).

To gauge the impact of accounting for this endogeneity, we estimated single equation results of the consequences of racial harassment on job dissatisfaction and intentions to leave military employment. These results are presented in Table $4 .{ }^{43}$ It is not surprising given $\rho_{23}$ is frequently negative and significant that single-equation estimates of the effect of job dissatisfaction on intentions to leave military employment are smaller than those resulting from the simultaneous equation model. For example, single equation models indicate that job dissatisfaction is associated with a 22.7 percentage point increase in the probability of intending to leave the military. This is in comparison to estimated effects of between 34.8 and 42.3 percentage points (depending on the underlying harassment measure) resulting from the simultaneous equation models. Furthermore, explicitly accounting for endogeneity also has large effects on the estimated consequences of harassment. Specifically, single equation models of the effect of threatening racial harassment on job dissatisfaction (intentions to leave military employment) indicate that harassment is associated with a 8.2 (1.9) percentage point increase in the probability of being dissatisfied with (intending to leave) military

\footnotetext{
${ }^{43}$ The conditional probability of harassment on intended job change in the single equation framework, using the chain rule, simply reduces to the marginal effect of racial harassment in the dissatisfaction equation times the marginal effect of job dissatisfaction in the intended job change equation. The standard errors are calculated using the "delta" method.
} 
employment in comparison to our estimate of 42.4 (7.6) percentage points when we explicitly account for endogeneity (see Tables 3 and 4). While similar results are found with respect to career-related discrimination, controlling for endogeneity eliminates the small, but significant effect of offensive racial encounters on intentions to leave the military.

\section{Table 4 Here}

\section{Conclusions}

Increased racial and ethnic diversity in U.S. employment seems inevitable in the face of the growing diversity in the population generally. This study adds to the literature on workplace diversity by examining the consequences of racial harassment for the job satisfaction and intended job change of personnel on active duty in the U.S. military. Our results indicate that racial and ethnic harassment is common in the military. Approximately, two-thirds of personnel on active-duty report experiencing offensive racial behaviors in the previous 12 months, while approximately one in ten report experiencing threatening racial incidents or career-related discrimination. This harassment has negative consequences for military personnel. Racial harassment of any type results in significantly more job dissatisfaction. Furthermore, threatening racial incidents and career-related discrimination heighten intentions to leave the military, though there is no significant effect of racially offensive behavior on the intended job change of active-duty military personnel. Finally, our results point to the importance of accounting for unobserved individual- and job-specific heterogeneity when assessing the 
consequences of racial harassment. Failure to account for this heterogeneity leads the estimated impact of racial harassment on job satisfaction and intended job change to be understated.

It is unclear the extent to which these specific patterns might also be extended to groups of civilian workers. The military has historically been relatively integrated when compared to other social institutions and the nature of military employment leads to frequent interracial interactions as personnel-particularly young enlisted men and women - live and work in close proximity with others outside their own racial and ethnic group. At the same time, military personnel do not have the same protection from racial discrimination as the rest of the population as court decisions have held that Title VII of the Civil Rights Act of 1964 pertains only to civilian employees of the armed forces (Smither and Houston, 1991). Complaints about discrimination are addressed through military rather than civilian courts raising the potential for disparity in responses to racial harassment.

What is clear is that there are strong incentives for employers (both civilian and military) to develop effective policies for managing workplace diversity. Employers who minimize worker discord and successfully capitalize on the increased creativity and enhanced problem-solving ability of diverse workgroups are likely to find that they have a competitive edge. To the extent that racial harassment affects employers' ability to recruit and retain high-quality workers, it leads to higher labor costs. ${ }^{44}$ Consequently, institutional arrangements that reduce the incidence of racial harassment are likely to be quite important. Our results indicate that training programs and the promotion of hotlines

\footnotetext{
${ }^{44}$ Similarly, Shields and Wheatly Price (2002b) conclude that racial harassment is a considerable problem for the National Health System in the UK.
} 
and formal procedures for addressing harassment issues - which may heighten awareness of racial harassment issues generally—are often associated with a significant reduction in the propensity to report experiencing racial harassment. Conversely, harassment is more prevalent at those installations where racial confrontation and social prescriptions barring inter-racial interactions are rife. 


\section{References}

Alesina, Alberto and Eliana La Ferrara, (2003). "Ethnic Diversity and Economic Performance", unpublished working paper.

Antecol, Heather and Deborah A. Cobb-Clark, 2003. ““'Does Sexual Harassment Training Change Attitudes? A View from the Federal Level”, Social Science Quarterly, 84 (4), December, pp. 826-842.

Antecol, Heather and Deborah A. Cobb-Clark, 2004a. "The Sexual Harassment of Female Active-Duty Personnel: Effects on Job Satisfaction and Intentions to Remain in the Military", unpublished working paper.

Antecol, Heather and Deborah A. Cobb-Clark, 2004b. "Identity and Racial Harassment", unpublished working paper.

Antecol, Heather and Peter Kuhn, 2000. "Gender as an Impediment to Labor Market Success: Why do Young Women Report Greater Harm?", Journal of Labor Economics, 18(4), October, pp. 702-728

Armed Forces Equal Opportunity Survey [CD-ROM]. (2000). Arlington, VA: DMDC [Producer and Distributor].

Bartel, Ann P., 1981. "Race Differences in Job Satisfaction: A Reappraisal", Journal of Human Resources, 16(1), pp. 294 - 303.

Bertrand, Marianne and Sendhil Mullainathan, 2001. "Do People Mean What They Say? Implications for Subjective Survey Data", American Economic Review, 91(2), May, pp. $67-72$.

Brewer, Marilynn B., 1999. "The Psychology of Prejudice: Ingroup Love or Outgroup Hate?", Journal of Social Issues, 55(3), pp. 429-444.

Cappellari, Lorenzo and Stephen Jenkins, 2003. Multivariate Probit Regression Using Simulated Maximum Likelihood. Stata Journal, 3(3), pp. 278-294.

Clark, Andrew E., 1996. "Job Satisfaction in Britain." British Journal of Industrial Relations. 34(2), June, pp. 189-217.

Clark, Andrew E., 1997. "Job Satisfaction and Gender: Why are Women So Happy at Work?" Labour Economics, 4(4), pp. 341-372.

Clark, Andrew E., 2001. "What really matters in a job? Hedonic measurement using quit data," Labour Economics, 8(2), pp. 223-242. 
Clark, Andrew E. and Andrew J. Oswald, 1996. "Satisfaction and Comparison Income." Journal of Public Economics, 61(3), pp. 359-381.

Clark, Andrew, Yannis Gerogellis and Peter Sanfey, 1998. "Job Satisfaction, Wage Changes, and Quits: Evidence from Germany", Research in Labour Economics, 17, pp. 95-121.

Clegg, Chris W., 1983. "Psychology of Employee Lateness, Absence, and Turnover: A Methodological Critique and an Empirical Study." Journal of Applied Psychology, 68, pp. 88-101.

Dansby, Mickey R. and Dan Landis, 2001. "Intercultural Training in the United States Military", in Managing Diversity in the Military, Dansby, M.R., Stewart, J.B, and Webb, S.C (eds.), New Brunswick, NJ: Transaction Publishers, pp. $163-177$.

Dansby, Mickey R., James B., and Schuyler C. Webb, 2001, Managing Diversity in the Military, New Brunswick, NJ: Transaction Publishers.

DOD, undated. Career Progression of Minority and Women Officers, Office of the Under Secretary of Defense, Personnel and Readiness.

Edwards, Jack E., 2001. “Opportunities for Assessing Military EO: A Researcher's Perspective on Identifying an Integrative Program-Evaluation Strategy" in Managing Diversity in the Military, Dansby, M.R., Stewart, J.B, and Webb, S.C (eds.), New Brunswick, NJ: Transaction Publishers, pp. $163-177$.

Elig, Timothy W., Jack E. Edwards, and Richard A. Riemer, 1997. Armed Forces 1996 Equal Opportunity Survey: Administration, Datasets, and Codebook (Report No. 97-026). Arlington, VA: Defense Manpower Data Center.

Ellison, Christopher G., 1992. "Military Background, Racial Orientations, and Political Participation among Black Adult Males”, Social Science Quarterly, 73(2), June, pp. 360-378.

Freeman, Ronald B., 1978. "Job Satisfaction as an Economic Variable". American Economic Review, 68, pp. 135-141.

Gordon, Michale E. and Angelo S. Denisi, 1995. "A Re-Examination of the Relationship Between Union Membership and Job Satisfaction", Industrial and Labor Relations Review, 48(2), January, pp. 222-236.

Greene, William H., 1997. Econometric Analysis, Third Edition, New Jersey: PrenticeHall. 
Hamermesh, Daniel S., 1977. "Economics Aspects of Job Satisfaction". In O. E. Ashenfelter and W. E. Oates, (eds.) Essays in Labor Market Analysis. New York: John Wiley.

Hamilton, Barton H., Jack A. Nicerson and Hideo Owan, 2004. "Diversity and Productivity in Production Teams", unpublished working paper.

Hampton, Mary B. and John S. Heywood, 1993. "Do Workers Accurately Perceive Gender Wage Discrimination?” Industrial and Labor Relations Review, 47(1), October, pp. 36-49.

Heywood, John S. and Xiangdong Wei, 2001. "Performance Pay and Job Satisfaction", unpublished working paper.

Hosek, James R. and Jennifer Sharp, 2001. Keeping Military Pay Competitive: The Outlook for Civilian Wage Growth and its Consequences. Santa Monica, CA: Rand.

Johnson, Richard W. and David Neumark, 1997. "Age Discrimination, Job Separations, and Employment Status of Older Workers: Evidence from Self-Report." Journal of Human Resources, 32(4), Fall, pp. 779-811.

Kilburn, Rebecca, Rachel Lowie, and Dana P. Goldman, 2001. Patterns of Enlisted Compensation. Santa Monica: RAND.

Knouse, Stephen B., 1991. "Introduction to Racial, Ethnic and Gender Issues in the Military: The Decade of the 1900s and Beyond", International Journal of Intercultural Relations, 15(4), pp. 385 - 388.

Kristensen, Nicolai and Niels Westergård-Neilsen, 2004. "Does Low Job Satisfaction Lead to Job Mobility?”, IZA Discussion Paper 1026, February 2004.

Kuhn, Peter. 1987. "Sex Discrimination in Labor Markets: The Role of Statistical Evidence”, American Economic Review, 77(4), September, pp. 567-583.

Laband, David N., and Bernard F. Lentz. 1998. "The Effects of Sexual Harassment on Job Satisfaction, Earnings, and Turnover Among Female Lawyers." Industrial and Labor Relations Review, 51(4), July, pp. 594-607.

Lazear, Edward P., 1999. "Globalisation and the Market for Team-Mates", The Economic Journal, 109, March, pp. c15- c40.

Lévy-Garboua, Louis and Claude Montmarquette, 1996. "Reported Job Satisfaction: What Does it Mean?", unpublished working paper, December. 
Locke, Edwin A., 1976. "The Nature and Causes of Job Satisfaction." In Marvin Dunnette (ed.) Hanbook of Industrial and Organizational Psychology.

Mangione, T. W., and R. P. Quinn, 1975. "Job Satisfaction, Counterproductive Behaviour and Drug Use at Work." Journal of Applied Psychology, 60. pp. 114-116.

Manski, Charles F., 1993. "Identification of Endogenous Socail Effects: The Reflection Problem”, The Review of Economic Studies, 60(3), July, pp. 531-542.

McClelland, Kent and Christopher Hunter, 1992. "The Perceived Seriousness of Racial Harassment”, Social Problems, 39(1), February, pp. 92 - 107.

Melese, Francois, James Blandin, and Phillip Fanchon, 1992. "Benefits and Pay: The Economics of Military Compensation, Defence Economics, 3, pp. 243-253.

Milliken, Frances J. and Luis L. Martins, 1996. "Searching for Common Threads: Understanding the Multiple Effects of Diversity in Organizational Groups", The Academy of Management Review, 21(2), April, pp. 402-433.

Moskos, Charles C. and John Sibley Butler, 1996. All That We Can Be: Black Leadership and Racial Integration the Army Way. New York: BasicBooks.

Rosen, Lenora N. and Lee Martin, 1997. "Sexual Harassment, Coehsion and Combat Readiness in U.S. Army Support Units", Armed Forces and Society, 24(2), Winter, pp. $221-244$.

Scarville, Jacquelyn, Scott B. Button, Jack E. Edwards, Anita R. Lancaster, and Timothy W. Elig, 1997. Armed Forces Equal Opportunity Survey (Report No. 97-027). Arlington, VA: Defense Manpower Data Center.

Shields, Michael A. \& Ward, Melanie, 2001. "Improving nurse retention in the National Health Service in England: the impact of job satisfaction on intentions to quit," Journal of Health Economics, 20(5), pp. 677-701.

Shields, Michael A. and Stephen Wheatly Price, 2002a. "The Determinants of Racial Harassment at the Workplace: Evidence from the British Nursing Profession", British Journal of Industrial Relations, 40(1), March, pp. 1-21.

Shields, Michael A. and Stephen Wheatly Price, 2002b. "Racial Harassment, Job Satisfaction and Intentions to Quit: Evidence from the British Nursing Profession", Economica, 69(274), May, pp. 295-326.

Smither, Robert D. and Mary Ruth Houston, 1991. "Racial Discrimination and Forms of Redress in the Military", International Journal of Intercultural Relations, 15(4), pp. 459-468. 
Steel, Robert P. and Nestor K. Orvalle, II, 1984. "A Review and Meta-Analysis of Research on the Relationship Between Behavioral Intentions and Employee Turnover", Journal of Applied Psychology, 69(4), pp. 673-686.

U.S. Census Bureau, 2001. Population by Race and Hispanic or Latino Origin for the United States: 1990 - 2000 (Census 2000 PHC-T- 1), internet release date April 2, 2001.

Wheeless, Sara C., Robert E. Manson, Jill D. Kavee, Richard A. Riemer, and Timothy W. Elig (1997). Armed Forces 1996 Equal Opportunity Survey: Statistical Methodology Report (Report No. 97-025). Arlington, VA: Defense Manpower Data Center.

Williams, Jill Hunter, Louise F. Fitzgerald, and Fritz Drasgow, 1999. "The Effects of Organizational Practices on Sexual Harassment and Individual Outcomes in the Military", Military Psychology, 11(3), pp. 303-328. 
Table 1. Reports of Racial Harasment, Job Dissatisfaction, and Intentions to Quit the Military

\begin{tabular}{|c|c|c|c|c|c|c|}
\hline & \multicolumn{2}{|c|}{ Reports of Behavior } & \multicolumn{2}{|c|}{ Dissatisfaction } & \multicolumn{2}{|c|}{ Quit } \\
\hline & Mean & Std. Dev. & Mean & Std. Dev. & Mean & Std. Dev. \\
\hline \multirow{4}{*}{$\begin{array}{l}\text { Overall } \\
\text { offense } \\
\text { threat } \\
\text { career }\end{array}$} & & & 0.169 & 0.375 & 0.267 & 0.442 \\
\hline & 0.651 & 0.477 & 0.192 & 0.394 & 0.286 & 0.452 \\
\hline & 0.090 & 0.286 & 0.304 & 0.460 & 0.391 & 0.488 \\
\hline & 0.128 & 0.334 & 0.311 & 0.463 & 0.363 & 0.481 \\
\hline & 0.167 & 0.373 & 0.276 & 0.447 \\
\hline offense & 0.609 & 0.488 & 0.189 & 0.392 & 0.300 & 0.458 \\
\hline threat & 0.075 & 0.263 & 0.289 & 0.454 & 0.406 & 0.492 \\
\hline career & 0.075 & 0.264 & 0.356 & 0.479 & 0.387 & 0.488 \\
\hline \multicolumn{3}{|l|}{ Black } & 0.181 & 0.385 & 0.248 & 0.432 \\
\hline offense & 0.750 & 0.433 & 0.204 & 0.403 & 0.260 & 0.439 \\
\hline threat & 0.128 & 0.334 & 0.313 & 0.464 & 0.378 & 0.485 \\
\hline career & 0.287 & 0.452 & 0.270 & 0.444 & 0.356 & 0.479 \\
\hline \multicolumn{3}{|l|}{ Hispanic } & 0.156 & 0.363 & 0.250 & 0.433 \\
\hline offense & 0.775 & 0.417 & 0.179 & 0.383 & 0.264 & 0.441 \\
\hline threat & 0.105 & 0.307 & 0.349 & 0.477 & 0.405 & 0.492 \\
\hline career & 0.200 & 0.400 & 0.280 & 0.449 & 0.324 & 0.468 \\
\hline \multicolumn{3}{|l|}{ Asian } & 0.151 & 0.358 & 0.200 & 0.400 \\
\hline offense & 0.668 & 0.471 & 0.180 & 0.384 & 0.227 & 0.419 \\
\hline threat & 0.142 & 0.349 & 0.266 & 0.443 & 0.318 & 0.467 \\
\hline career & 0.164 & 0.370 & 0.311 & 0.464 & 0.333 & 0.472 \\
\hline \multicolumn{3}{|c|}{ Native American } & 0.241 & 0.428 & 0.275 & 0.447 \\
\hline offense & 0.727 & 0.446 & 0.304 & 0.460 & 0.327 & 0.469 \\
\hline threat & 0.157 & 0.364 & 0.485 & 0.502 & 0.222 & 0.417 \\
\hline career & 0.186 & 0.389 & 0.432 & 0.497 & 0.333 & 0.473 \\
\hline
\end{tabular}

Sampling weights used. Number of observations are 19,184, 5,142, 4,253, 4,802, 3,682, and 1,305 for the overall, white, black,

Hispanic, Asian, and Native American samples, respectively. 
Table 2. Determinants of Racial Harassment

(Trivariate Probit Marginal Effects and Standard Errors)

\begin{tabular}{|c|c|c|c|c|c|c|c|c|c|c|c|c|}
\hline & \multicolumn{6}{|c|}{ Offense } & \multicolumn{6}{|c|}{ Threat } \\
\hline & Overall & White & Black & Hispanic & Asian & $\begin{array}{r}\text { Native } \\
\text { American }\end{array}$ & Overall & White & Black & Hispanic & Asian & $\begin{array}{r}\text { Native } \\
\text { American }\end{array}$ \\
\hline \multicolumn{13}{|l|}{ Race } \\
\hline \multirow[t]{2}{*}{ Black } & 0.068 & & & & & & 0.011 & & & & & \\
\hline & $(0.017)$ & & & & & & $(0.011)$ & & & & & \\
\hline \multirow[t]{2}{*}{ Hispanic } & 0.067 & & & & & & -0.014 & & & & & \\
\hline & $(0.019)$ & & & & & & $(0.009)$ & & & & & \\
\hline \multirow[t]{2}{*}{ Asian } & -0.064 & & & & & & 0.010 & & & & & \\
\hline & $(0.025)$ & & & & & & $(0.016)$ & & & & & \\
\hline \multirow[t]{2}{*}{ Native American } & -0.048 & & & & & & 0.009 & & & & & \\
\hline & $(0.052)$ & & & & & & $(0.033)$ & & & & & \\
\hline \multicolumn{13}{|c|}{ Awareness of Racial Harassment Programs } \\
\hline \multirow[t]{2}{*}{ Training } & -0.023 & -0.004 & -0.061 & -0.032 & -0.041 & -0.165 & -0.015 & 0.001 & -0.047 & -0.052 & -0.012 & -0.143 \\
\hline & $(0.014)$ & $(0.019)$ & $(0.015)$ & $(0.029)$ & $(0.030)$ & $(0.044)$ & $(0.008)$ & $(0.008)$ & $(0.021)$ & $(0.013)$ & $(0.019)$ & $(0.055)$ \\
\hline \multirow[t]{2}{*}{ Hotlines } & -0.064 & -0.052 & -0.059 & -0.083 & -0.190 & -0.006 & -0.023 & -0.022 & -0.012 & -0.019 & -0.080 & -0.040 \\
\hline & $(0.016)$ & $(0.023)$ & $(0.021)$ & $(0.028)$ & $(0.051)$ & $(0.061)$ & (0.009) & $(0.012)$ & $(0.018)$ & $(0.015)$ & $(0.034)$ & $(0.043)$ \\
\hline \multirow[t]{2}{*}{ Channels } & -0.045 & -0.050 & -0.046 & -0.025 & 0.015 & -0.107 & -0.043 & -0.038 & -0.072 & -0.043 & -0.038 & 0.054 \\
\hline & $(0.018)$ & $(0.027)$ & $(0.022)$ & $(0.026)$ & $(0.047)$ & $(0.060)$ & $(0.010)$ & $(0.015)$ & $(0.020)$ & $(0.019)$ & $(0.030)$ & $(0.050)$ \\
\hline \multicolumn{13}{|l|}{ Equal Opportunity Climate* } \\
\hline \multirow[t]{2}{*}{ Racial Confrontation } & 0.253 & 0.224 & 0.340 & 0.137 & 0.007 & 1.000 & 0.099 & 0.133 & 0.050 & -0.010 & -0.046 & -0.082 \\
\hline & $(0.085)$ & $(0.118)$ & $(0.104)$ & $(0.146)$ & $(0.133)$ & $(0.320)$ & $(0.036)$ & $(0.045)$ & $(0.066)$ & $(0.078)$ & $(0.085)$ & $(0.187)$ \\
\hline \multirow{2}{*}{$\begin{array}{r}\text { Reports of Harassment } \\
\text { w/o Repercussions }\end{array}$} & 0.093 & 0.157 & 0.012 & -0.030 & -0.238 & 0.211 & -0.055 & -0.047 & -0.015 & -0.102 & -0.235 & -0.537 \\
\hline & $(0.075)$ & $(0.106)$ & $(0.126)$ & $(0.134)$ & $(0.201)$ & $(0.270)$ & $(0.040)$ & $(0.050)$ & $(0.091)$ & $(0.089)$ & $(0.107)$ & $(0.206)$ \\
\hline \multirow[t]{2}{*}{ Hotlines } & -0.008 & -0.100 & 0.177 & 0.011 & 0.146 & 1.221 & 0.043 & 0.067 & 0.068 & -0.092 & -0.262 & 0.302 \\
\hline & $(0.086)$ & $(0.122)$ & $(0.139)$ & $(0.121)$ & $(0.175)$ & $(0.408)$ & $(0.051)$ & $(0.067)$ & $(0.117)$ & $(0.104)$ & $(0.142)$ & $(0.299)$ \\
\hline \multirow[t]{2}{*}{ Channels } & 0.092 & 0.145 & -0.075 & 0.138 & -0.024 & -0.968 & 0.030 & -0.015 & 0.123 & 0.041 & 0.139 & 0.250 \\
\hline & $(0.078)$ & $(0.109)$ & $(0.140)$ & $(0.130)$ & $(0.173)$ & $(0.453)$ & $(0.055)$ & $(0.077)$ & $(0.106)$ & $(0.100)$ & $(0.143)$ & $(0.338)$ \\
\hline \multirow[t]{2}{*}{ Social Prescriptions* } & -0.031 & -0.041 & -0.011 & -0.010 & -0.004 & 0.024 & -0.007 & 0.002 & -0.035 & -0.010 & -0.019 & -0.029 \\
\hline & $(0.009)$ & $(0.012)$ & $(0.015)$ & $(0.019)$ & $(0.017)$ & $(0.037)$ & $(0.005)$ & $(0.007)$ & $(0.010)$ & $(0.011)$ & $(0.016)$ & $(0.028)$ \\
\hline \multicolumn{13}{|c|}{ Workplace Inter-racial Interactions } \\
\hline \multirow[t]{2}{*}{ Race Uncommon } & 0.142 & 0.173 & 0.110 & 0.094 & 0.100 & 0.184 & 0.045 & 0.051 & 0.027 & 0.063 & 0.086 & 0.051 \\
\hline & $(0.015)$ & $(0.036)$ & $(0.021)$ & $(0.017)$ & $(0.029)$ & $(0.066)$ & $(0.013)$ & $(0.027)$ & $(0.020)$ & $(0.013)$ & $(0.021)$ & $(0.042)$ \\
\hline \multirow[t]{2}{*}{ Race of Supervisor Different } & 0.020 & 0.006 & 0.018 & 0.033 & -0.016 & & 0.017 & 0.020 & 0.006 & -0.026 & 0.032 & \\
\hline & $(0.017)$ & $(0.023)$ & $(0.023)$ & $(0.036)$ & $(0.052)$ & & $(0.010)$ & $(0.011)$ & $(0.019)$ & $(0.026)$ & $(0.027)$ & \\
\hline
\end{tabular}


Table 2. Determinants of Racial Harassment--Continued (Trivariate Probit Marginal Effects and Standard Errors)

\begin{tabular}{|c|c|c|c|c|c|c|}
\hline & \multicolumn{6}{|c|}{ Career } \\
\hline & Overall & White & Black & Hispanic & Asian & $\begin{array}{r}\text { Native } \\
\text { American }\end{array}$ \\
\hline \multicolumn{7}{|l|}{ Race } \\
\hline Black & $\begin{array}{r}\mathbf{0 . 1 2 5} \\
(0.016)\end{array}$ & & & & & \\
\hline Hispanic & $\begin{array}{r}\mathbf{0 . 0 3 6} \\
(0.013)\end{array}$ & & & & & \\
\hline Asian & $\begin{array}{r}-0.009 \\
(0.015)\end{array}$ & & & & & \\
\hline Native American & $\begin{array}{r}-0.009 \\
(0.026)\end{array}$ & & & & & \\
\hline \multicolumn{7}{|c|}{ Awareness of Racial Harassment Programs } \\
\hline Training & $\begin{array}{r}\mathbf{- 0 . 0 3 3} \\
(0.008)\end{array}$ & $\begin{array}{r}-0.008 \\
(0.009)\end{array}$ & $\begin{array}{r}\mathbf{- 0 . 0 9 7} \\
(0.020)\end{array}$ & $\begin{array}{r}\mathbf{- 0 . 0 6 5} \\
(0.018)\end{array}$ & $\begin{array}{r}\mathbf{- 0 . 0 6 3} \\
(0.021)\end{array}$ & $\begin{array}{r}\mathbf{- 0 . 2 6 0} \\
(0.059)\end{array}$ \\
\hline Hotlines & $\begin{array}{r}\mathbf{- 0 . 0 5 5} \\
(0.012)\end{array}$ & $\begin{array}{r}\mathbf{- 0 . 0 4 5} \\
(0.013)\end{array}$ & $\begin{array}{r}\mathbf{- 0 . 0 7 2} \\
(0.025)\end{array}$ & $\begin{array}{r}-0.050 \\
(0.027)\end{array}$ & $\begin{array}{r}\mathbf{- 0 . 1 1 2} \\
(0.036)\end{array}$ & $\begin{array}{r}-0.062 \\
(0.062)\end{array}$ \\
\hline Channels & $\begin{array}{r}\mathbf{- 0 . 0 2 2} \\
(0.011)\end{array}$ & $\begin{array}{r}-0.003 \\
(0.012)\end{array}$ & $\begin{array}{r}\mathbf{- 0 . 0 9 5} \\
(0.028)\end{array}$ & $\begin{array}{r}\mathbf{- 0 . 0 6 0} \\
(0.024)\end{array}$ & $\begin{array}{r}-0.027 \\
(0.032)\end{array}$ & $\begin{array}{r}-0.010 \\
(0.057)\end{array}$ \\
\hline \multicolumn{7}{|l|}{ Equal Opportunity Climate* } \\
\hline Racial Confrontation & $\begin{array}{r}0.027 \\
(0.050)\end{array}$ & $\begin{array}{r}-0.001 \\
(0.054)\end{array}$ & $\begin{array}{r}0.115 \\
(0.112)\end{array}$ & $\begin{array}{r}0.224 \\
(0.121)\end{array}$ & $\begin{array}{r}-0.200 \\
(0.124)\end{array}$ & $\begin{array}{r}-0.435 \\
(0.220)\end{array}$ \\
\hline $\begin{array}{r}\text { Reports of Harassment } \\
\text { w/o Repercussions }\end{array}$ & $\begin{array}{r}-0.027 \\
(0.043)\end{array}$ & $\begin{array}{r}0.014 \\
(0.051)\end{array}$ & $\begin{array}{r}-0.104 \\
(0.131)\end{array}$ & $\begin{array}{r}-0.138 \\
(0.129)\end{array}$ & $\begin{array}{r}-0.123 \\
(0.152)\end{array}$ & $\begin{array}{r}\mathbf{- 0 . 6 3 4} \\
(0.231)\end{array}$ \\
\hline Hotlines & $\begin{array}{r}-0.045 \\
(0.055)\end{array}$ & $\begin{array}{r}-0.057 \\
(0.060)\end{array}$ & $\begin{array}{r}0.090 \\
(0.136)\end{array}$ & $\begin{array}{r}0.003 \\
(0.155)\end{array}$ & $\begin{array}{r}-0.221 \\
(0.151)\end{array}$ & $\begin{array}{r}-0.072 \\
(0.237)\end{array}$ \\
\hline Channels & $\begin{array}{r}\mathbf{0 . 1 2 9} \\
(0.056)\end{array}$ & $\begin{array}{r}0.100 \\
(0.071)\end{array}$ & $\begin{array}{r}0.130 \\
(0.126)\end{array}$ & $\begin{array}{r}0.101 \\
(0.154)\end{array}$ & $\begin{array}{r}0.171 \\
(0.164)\end{array}$ & $\begin{array}{r}0.232 \\
(0.226)\end{array}$ \\
\hline Social Prescriptions* & $\begin{array}{r}\mathbf{- 0 . 0 1 6} \\
(0.005)\end{array}$ & $\begin{array}{r}\mathbf{- 0 . 0 1 3} \\
(0.006)\end{array}$ & $\begin{array}{r}\mathbf{- 0 . 0 3 4} \\
(0.014)\end{array}$ & $\begin{array}{r}-0.003 \\
(0.014)\end{array}$ & $\begin{array}{r}-0.020 \\
(0.015)\end{array}$ & $\begin{array}{r}-0.014 \\
(0.022)\end{array}$ \\
\hline \multicolumn{7}{|c|}{ Workplace Inter-racial Interactions } \\
\hline Race Uncommon & $\begin{array}{r}\mathbf{0 . 1 0 2} \\
(0.014)\end{array}$ & $\begin{array}{r}\mathbf{0 . 1 0 5} \\
(0.029)\end{array}$ & $\begin{array}{r}\mathbf{0 . 1 3 4} \\
(0.028)\end{array}$ & $\begin{array}{r}\mathbf{0 . 1 3 5} \\
(0.022)\end{array}$ & $\begin{array}{r}\mathbf{0 . 0 6 8} \\
(0.023)\end{array}$ & $\begin{array}{r}-0.047 \\
(0.053)\end{array}$ \\
\hline Race of Supervisor Different & $\begin{array}{r}\mathbf{0 . 0 4 7} \\
(0.010)\end{array}$ & $\begin{array}{r}\mathbf{0 . 0 3 7} \\
(0.013)\end{array}$ & $\begin{array}{r}\mathbf{0 . 0 4 4} \\
(0.021)\end{array}$ & $\begin{array}{r}0.019 \\
(0.030)\end{array}$ & $\begin{array}{r}0.056 \\
(0.025)\end{array}$ & \\
\hline
\end{tabular}

Sampling weights used. Number of observations are 19,184, 5,142, 4,253,4,802, 3,682, and 1,305 for the overall, white, black, Hispanic, Asian, and Native American samples, respectively. The racial harassment equation also includes controls for background characteristics, installation specific measures of diversity, overall race relations, and a constant. Standard errors are adjusted for clustering by installation.

* indicates installation-level variables. Bold (shaded) indicates significant at the 5 (10) percent level. 
Table 3. Determinants of Job Dissatisfaction and Intentions to Quit the Military (Trivariate Probit Marginal Effects and Standard Errors)

\begin{tabular}{|c|c|c|c|c|c|c|c|c|c|c|c|c|}
\hline & \multicolumn{6}{|c|}{ Dissatisfaction } & \multicolumn{6}{|c|}{ Quit } \\
\hline & Overall & White & Black & Hispanic & Asian & $\begin{array}{r}\text { Native } \\
\text { American }\end{array}$ & Overall & White & Black & Hispanic & Asian & $\begin{array}{l}\text { Native } \\
\text { American }\end{array}$ \\
\hline Offense & $\begin{array}{r}\mathbf{0 . 3 0 7} \\
(0.030)\end{array}$ & $\begin{array}{r}\mathbf{0 . 3 0 7} \\
(0.044)\end{array}$ & $\begin{array}{r}\mathbf{0 . 3 1 5} \\
(0.023)\end{array}$ & $\begin{array}{r}\mathbf{0 . 2 1 0} \\
(0.081)\end{array}$ & $\begin{array}{r}\mathbf{0 . 2 5 3} \\
(0.055)\end{array}$ & $\begin{array}{r}\mathbf{0 . 3 7 1} \\
(0.070)\end{array}$ & $\begin{array}{r}-0.039 \\
(0.035)\end{array}$ & $\begin{array}{r}-0.031 \\
(0.039)\end{array}$ & $\begin{array}{r}\mathbf{- 0 . 1 2 0} \\
(0.038)\end{array}$ & $\begin{array}{r}-0.028 \\
(0.548)\end{array}$ & $\begin{array}{r}-0.117 \\
(0.458)\end{array}$ & $\begin{array}{r}0.115 \\
(1.406)\end{array}$ \\
\hline Dissatisfaction & & & & & & & $\begin{array}{r}\mathbf{0 . 3 4 8} \\
(0.096)\end{array}$ & $\begin{array}{r}\mathbf{0 . 3 6 7} \\
(0.131)\end{array}$ & $\begin{array}{r}\mathbf{0 . 3 7 5} \\
(0.089)\end{array}$ & $\begin{array}{r}0.281 \\
(0.162)\end{array}$ & $\begin{array}{r}\mathbf{0 . 6 2 2} \\
(0.072)\end{array}$ & $\begin{array}{r}0.008 \\
(0.153)\end{array}$ \\
\hline \multicolumn{13}{|l|}{ Race } \\
\hline Black & $\begin{array}{r}\mathbf{- 0 . 0 4 4} \\
(0.013)\end{array}$ & & & & & & $\begin{array}{r}\mathbf{- 0 . 0 3 2} \\
(0.014)\end{array}$ & & & & & \\
\hline Hispanic & $\begin{array}{r}\mathbf{- 0 . 0 6 0} \\
(0.014)\end{array}$ & & & & & & $\begin{array}{r}\mathbf{- 0 . 0 5 1} \\
(0.014)\end{array}$ & & & & & \\
\hline Asian & $\begin{array}{r}-0.030 \\
(0.019)\end{array}$ & & & & & & $\begin{array}{r}\mathbf{- 0 . 0 8 0} \\
(0.016)\end{array}$ & & & & & \\
\hline Native American & $\begin{array}{r}0.027 \\
(0.039)\end{array}$ & & & & & & $\begin{array}{r}-0.040 \\
(0.040)\end{array}$ & & & & & \\
\hline \multicolumn{13}{|c|}{ Workplace Inter-racial Interactions } \\
\hline Race Uncommon & $\begin{array}{r}-0.021 \\
(0.020)\end{array}$ & $\begin{array}{r}-0.019 \\
(0.039)\end{array}$ & $\begin{array}{r}\mathbf{- 0 . 0 5 2} \\
(0.018)\end{array}$ & $\begin{array}{r}0.001 \\
(0.027)\end{array}$ & $\begin{array}{r}-0.007 \\
(0.031)\end{array}$ & $\begin{array}{r}0.017 \\
(0.090)\end{array}$ & & & & & & \\
\hline Race of Supervisor Different & $\begin{array}{r}0.002 \\
(0.015)\end{array}$ & $\begin{array}{r}0.011 \\
(0.020)\end{array}$ & $\begin{array}{r}0.007 \\
(0.018)\end{array}$ & $\begin{array}{r}-0.013 \\
(0.030)\end{array}$ & $\begin{array}{r}0.023 \\
(0.034)\end{array}$ & & & & & & & \\
\hline \multicolumn{13}{|l|}{ Civilian Opportunities Better } \\
\hline Promotion & $\begin{array}{r}\mathbf{0 . 0 4 9} \\
(0.015)\end{array}$ & $\begin{array}{r}\mathbf{0 . 0 5 6} \\
(0.019)\end{array}$ & $\begin{array}{r}0.009 \\
(0.022)\end{array}$ & $\begin{array}{r}\mathbf{0 . 0 6 7} \\
(0.037)\end{array}$ & $\begin{array}{r}0.055 \\
(0.050)\end{array}$ & $\begin{array}{r}-0.013 \\
(0.064)\end{array}$ & & & & & & \\
\hline Pay and Benefits & $\begin{array}{r}0.012 \\
(0.011)\end{array}$ & $\begin{array}{r}0.006 \\
(0.016)\end{array}$ & $\begin{array}{r}0.021 \\
(0.015)\end{array}$ & $\begin{array}{r}0.005 \\
(0.018)\end{array}$ & $\begin{array}{r}0.057 \\
(0.031)\end{array}$ & $\begin{array}{r}\mathbf{0 . 2 2 1} \\
(0.075)\end{array}$ & & & & & & \\
\hline Fair Performance Evaluations & $\begin{array}{r}\mathbf{0 . 0 4 4} \\
(0.016)\end{array}$ & $\begin{array}{r}0.022 \\
(0.024)\end{array}$ & $\begin{array}{r}\mathbf{0 . 0 7 2} \\
(0.025)\end{array}$ & $\begin{array}{r}\mathbf{0 . 1 0 5} \\
(0.036)\end{array}$ & $\begin{array}{r}0.076 \\
(0.050)\end{array}$ & $\begin{array}{r}0.056 \\
(0.073)\end{array}$ & & & & & & \\
\hline Education and Training & $\begin{array}{r}\mathbf{0 . 1 1 5} \\
(0.017)\end{array}$ & $\begin{array}{r}\mathbf{0 . 1 4 4} \\
(0.028)\end{array}$ & $\begin{array}{r}\mathbf{0 . 0 9 0} \\
(0.021)\end{array}$ & $\begin{array}{r}\mathbf{0 . 0 6 8} \\
(0.028)\end{array}$ & $\begin{array}{r}\mathbf{0 . 0 6 8} \\
(0.031)\end{array}$ & $\begin{array}{r}-0.106 \\
(0.071)\end{array}$ & & & & & & \\
\hline Quality of Life & & & & & & & $\begin{array}{r}\mathbf{0 . 0 8 8} \\
(0.014)\end{array}$ & $\begin{array}{r}\mathbf{0 . 0 7 2} \\
(0.018)\end{array}$ & $\begin{array}{r}\mathbf{0 . 1 4 9} \\
(0.023)\end{array}$ & $\begin{array}{r}\mathbf{0 . 1 3 5} \\
(0.027)\end{array}$ & $\begin{array}{r}0.034 \\
(0.024)\end{array}$ & $\begin{array}{r}0.074 \\
(0.079)\end{array}$ \\
\hline $\begin{array}{r}\text { Chance to Show Pride } \\
\text { in Yourself }\end{array}$ & & & & & & & $\begin{array}{r}\mathbf{0 . 1 3 4} \\
(0.024)\end{array}$ & $\begin{array}{r}\mathbf{0 . 1 4 0} \\
(0.035)\end{array}$ & $\begin{array}{r}\mathbf{0 . 1 1 5} \\
(0.032)\end{array}$ & $\begin{array}{r}\mathbf{0 . 1 3 1} \\
(0.039)\end{array}$ & $\begin{array}{r}0.041 \\
(0.040)\end{array}$ & $\begin{array}{r}\mathbf{0 . 3 5 9} \\
(0.090)\end{array}$ \\
\hline Family Situation & & & & & & & & & & & & \\
\hline Married & & & & & & & $\begin{array}{r}\mathbf{- 0 . 0 4 9} \\
(0.014)\end{array}$ & $\begin{array}{r}\mathbf{- 0 . 0 4 4} \\
(0.020)\end{array}$ & $\begin{array}{r}-0.033 \\
(0.021)\end{array}$ & $\begin{array}{r}\mathbf{- 0 . 0 9 3} \\
(0.027)\end{array}$ & $\begin{array}{r}-0.015 \\
(0.025)\end{array}$ & $\begin{array}{r}-0.128 \\
(0.076)\end{array}$ \\
\hline Presence of Children & & & & & & & $\begin{array}{r}\mathbf{- 0 . 0 3 8} \\
(0.024)\end{array}$ & $\begin{array}{r}\mathbf{- 0 . 0 4 6} \\
(0.021)\end{array}$ & $\begin{array}{r}0.003 \\
(0.021)\end{array}$ & $\begin{array}{r}\mathbf{- 0 . 0 7 0} \\
(0.025)\end{array}$ & $\begin{array}{r}\mathbf{- 0 . 0 9 0} \\
(0.022)\end{array}$ & $\begin{array}{r}0.133 \\
(0.071)\end{array}$ \\
\hline
\end{tabular}


Table 3. Determinants of Job Dissatisfaction and Intentions to Quit the Military--Continued (Trivariate Probit Marginal Effects and Standard Errors)

\begin{tabular}{|c|c|c|c|c|c|c|c|c|c|c|c|c|}
\hline & \multicolumn{6}{|c|}{ Dissatisfaction } & \multicolumn{6}{|c|}{ Quit } \\
\hline & Overall & White & Black & Hispanic & Asian & $\begin{array}{r}\text { Native } \\
\text { American }\end{array}$ & Overall & White & Black & Hispanic & Asian & $\begin{array}{r}\text { Native } \\
\text { American }\end{array}$ \\
\hline Threat & $\begin{array}{r}\mathbf{0 . 4 2 4} \\
(0.052)\end{array}$ & $\begin{array}{r}0.196 \\
(0.150)\end{array}$ & $\begin{array}{r}\mathbf{0 . 3 8 2} \\
(0.084)\end{array}$ & $\begin{array}{r}\mathbf{0 . 3 8 8} \\
(0.098)\end{array}$ & $\begin{array}{r}\mathbf{0 . 3 7 2} \\
(0.142)\end{array}$ & $\begin{array}{r}\mathbf{0 . 7 1 0} \\
(0.055)\end{array}$ & $\begin{array}{r}\mathbf{0 . 0 7 6} \\
(0.037)\end{array}$ & $\begin{array}{r}0.065 \\
(0.081)\end{array}$ & $\begin{array}{r}\mathbf{0 . 1 1 8} \\
(0.040)\end{array}$ & $\begin{array}{r}0.085 \\
(0.047)\end{array}$ & $\begin{array}{r}0.174 \\
(2.032)\end{array}$ & $\begin{array}{r}-0.064 \\
(2.805)\end{array}$ \\
\hline Dissatisfaction & & & & & & & $\begin{array}{r}\mathbf{0 . 3 7 7} \\
(0.089)\end{array}$ & $\begin{array}{r}\mathbf{0 . 3 6 6} \\
(0.160)\end{array}$ & $\begin{array}{r}\mathbf{0 . 4 1 6} \\
(0.087)\end{array}$ & $\begin{array}{r}\mathbf{0 . 3 1 2} \\
(0.171)\end{array}$ & $\begin{array}{r}\mathbf{0 . 6 3 8} \\
(0.085)\end{array}$ & $\begin{array}{r}0.066 \\
(0.195)\end{array}$ \\
\hline \multicolumn{13}{|l|}{ Race } \\
\hline Black & $\begin{array}{r}-0.020 \\
(0.014)\end{array}$ & & & & & & $\begin{array}{r}\mathbf{- 0 . 0 3 2} \\
(0.014)\end{array}$ & & & & & \\
\hline Hispanic & $\begin{array}{r}\mathbf{- 0 . 0 3 3} \\
(0.015)\end{array}$ & & & & & & $\begin{array}{r}\mathbf{- 0 . 0 5 1} \\
(0.014)\end{array}$ & & & & & \\
\hline Asian & $\begin{array}{r}\mathbf{- 0 . 0 5 2} \\
(0.017)\end{array}$ & & & & & & $\begin{array}{r}\mathbf{- 0 . 0 8 0} \\
(0.016)\end{array}$ & & & & & \\
\hline Native American & $\begin{array}{r}0.012 \\
(0.037)\end{array}$ & & & & & & $\begin{array}{r}-0.041 \\
(0.041)\end{array}$ & & & & & \\
\hline \multicolumn{13}{|c|}{ Workplace Inter-racial Interactions } \\
\hline Race Uncommon & $\begin{array}{r}0.018 \\
(0.019)\end{array}$ & $\begin{array}{r}0.036 \\
(0.041)\end{array}$ & $\begin{array}{r}0.004 \\
(0.018)\end{array}$ & $\begin{array}{r}0.012 \\
(0.017)\end{array}$ & $\begin{array}{r}0.001 \\
(0.033)\end{array}$ & $\begin{array}{r}0.068 \\
(0.062)\end{array}$ & & & & & & \\
\hline Race of Supervisor Different & $\begin{array}{r}0.007 \\
(0.013)\end{array}$ & $\begin{array}{r}0.007 \\
(0.018)\end{array}$ & $\begin{array}{r}0.016 \\
(0.021)\end{array}$ & $\begin{array}{r}0.011 \\
(0.024)\end{array}$ & $\begin{array}{r}0.013 \\
(0.032)\end{array}$ & & & & & & & \\
\hline \multicolumn{13}{|l|}{ Civilian Opportunities Better } \\
\hline Promotion & $\begin{array}{r}\mathbf{0 . 0 5 2} \\
(0.016)\end{array}$ & $\begin{array}{r}\mathbf{0 . 0 5 9} \\
(0.020)\end{array}$ & $\begin{array}{r}0.016 \\
(0.023)\end{array}$ & $\begin{array}{r}0.065 \\
(0.040)\end{array}$ & $\begin{array}{r}0.055 \\
(0.059)\end{array}$ & $\begin{array}{r}0.060 \\
(0.090)\end{array}$ & & & & & & \\
\hline Pay and Benefits & $\begin{array}{r}0.014 \\
(0.012)\end{array}$ & $\begin{array}{r}0.009 \\
(0.017)\end{array}$ & $\begin{array}{r}0.018 \\
(0.016)\end{array}$ & $\begin{array}{r}0.008 \\
(0.018)\end{array}$ & $\begin{array}{r}0.056 \\
(0.035)\end{array}$ & $\begin{array}{r}\mathbf{0 . 1 7 4} \\
(0.089)\end{array}$ & & & & & & \\
\hline Fair Performance Evaluations & $\begin{array}{r}\mathbf{0 . 0 4 8} \\
(0.016)\end{array}$ & $\begin{array}{r}0.028 \\
(0.025)\end{array}$ & $\begin{array}{r}\mathbf{0 . 0 8 6} \\
(0.028)\end{array}$ & $\begin{array}{r}\mathbf{0 . 1 0 0} \\
(0.034)\end{array}$ & $\begin{array}{r}0.081 \\
(0.052)\end{array}$ & $\begin{array}{r}\mathbf{0 . 1 3 2} \\
(0.069)\end{array}$ & & & & & & \\
\hline Education and Training & $\begin{array}{r}\mathbf{0 . 1 2 1} \\
(0.019)\end{array}$ & $\begin{array}{r}\mathbf{0 . 1 5 3} \\
(0.033)\end{array}$ & $\begin{array}{r}\mathbf{0 . 0 9 3} \\
(0.023)\end{array}$ & $\begin{array}{r}\mathbf{0 . 0 6 3} \\
(0.027)\end{array}$ & $\begin{array}{r}\mathbf{0 . 0 6 5} \\
(0.036)\end{array}$ & $\begin{array}{r}-0.064 \\
(0.075)\end{array}$ & & & & & & \\
\hline Quality of Life & & & & & & & $\begin{array}{r}\mathbf{0 . 0 8 6} \\
(0.013)\end{array}$ & $\begin{array}{r}\mathbf{0 . 0 7 2} \\
(0.019)\end{array}$ & $\begin{array}{r}\mathbf{0 . 1 4 4} \\
(0.023)\end{array}$ & $\begin{array}{r}\mathbf{0 . 1 3 3} \\
(0.027)\end{array}$ & $\begin{array}{r}0.033 \\
(0.023)\end{array}$ & $\begin{array}{r}0.077 \\
(0.080)\end{array}$ \\
\hline $\begin{array}{c}\text { Chance to Show Pride } \\
\text { in Yourself }\end{array}$ & & & & & & & $\begin{array}{r}\mathbf{0 . 1 2 7} \\
(0.024)\end{array}$ & $\begin{array}{r}\mathbf{0 . 1 3 5} \\
(0.038)\end{array}$ & $\begin{array}{r}\mathbf{0 . 1 0 9} \\
(0.033)\end{array}$ & $\begin{array}{r}\mathbf{0 . 1 2 2} \\
(0.040)\end{array}$ & $\begin{array}{r}0.039 \\
(0.040)\end{array}$ & $\begin{array}{r}\mathbf{0 . 3 3 9} \\
(0.091)\end{array}$ \\
\hline Family Situation & & & & & & & & & & & & \\
\hline Married & & & & & & & $\begin{array}{r}\mathbf{- 0 . 0 4 9} \\
(0.014)\end{array}$ & $\begin{array}{r}\mathbf{- 0 . 0 4 4} \\
(0.020)\end{array}$ & $\begin{array}{r}-0.031 \\
(0.021)\end{array}$ & $\begin{array}{r}\mathbf{- 0 . 0 9 1} \\
(0.027)\end{array}$ & $\begin{array}{r}-0.017 \\
(0.024)\end{array}$ & $\begin{array}{r}-0.132 \\
(0.075)\end{array}$ \\
\hline Presence of Children & & & & & & & $\begin{array}{r}\mathbf{- 0 . 0 3 9} \\
(0.014)\end{array}$ & $\begin{array}{r}\mathbf{- 0 . 0 4 6} \\
(0.021)\end{array}$ & $\begin{array}{r}0.001 \\
(0.021)\end{array}$ & $\begin{array}{r}\mathbf{- 0 . 0 7 1} \\
(0.025)\end{array}$ & $\begin{array}{r}\mathbf{- 0 . 0 9 0} \\
(0.022)\end{array}$ & $\begin{array}{r}0.135 \\
(0.070)\end{array}$ \\
\hline
\end{tabular}


Table 3. Determinants of Job Dissatisfaction and Intentions to Quit the Military--Continued (Trivariate Probit Marginal Effects and Standard Errors)

\begin{tabular}{|c|c|c|c|c|c|c|c|c|c|c|c|c|}
\hline & \multicolumn{6}{|c|}{ Dissatisfaction } & \multicolumn{6}{|c|}{ Quit } \\
\hline & Overall & White & Black & Hispanic & Asian & $\begin{array}{r}\text { Native } \\
\text { American }\end{array}$ & Overall & White & Black & Hispanic & Asian & $\begin{array}{r}\text { Native } \\
\text { American }\end{array}$ \\
\hline \multirow[t]{2}{*}{ Career } & 0.422 & 0.393 & 0.408 & 0.385 & 0.484 & 0.504 & 0.078 & 0.056 & 0.060 & 0.045 & 0.000 & -0.019 \\
\hline & $(0.050)$ & $(0.130)$ & $(0.047)$ & $(0.104)$ & $(0.104)$ & $(0.246)$ & $(0.029)$ & $(0.054)$ & $(0.021)$ & $(0.027)$ & $(0.036)$ & $(4.854)$ \\
\hline \multirow[t]{2}{*}{ Dissatisfaction } & & & & & & & 0.423 & 0.381 & 0.444 & 0.264 & 0.604 & -0.059 \\
\hline & & & & & & & $(0.076)$ & $(0.137)$ & $(0.071)$ & $(0.156)$ & $(0.093)$ & $(0.271)$ \\
\hline \multicolumn{13}{|l|}{ Race } \\
\hline \multirow[t]{2}{*}{ Black } & $-\mathbf{0 . 0 5 7}$ & & & & & & -0.031 & & & & & \\
\hline & $(0.013)$ & & & & & & $(0.014)$ & & & & & \\
\hline \multirow[t]{2}{*}{ Hispanic } & -0.047 & & & & & & -0.049 & & & & & \\
\hline & $(0.014)$ & & & & & & $(0.014)$ & & & & & \\
\hline \multirow[t]{2}{*}{ Asian } & -0.040 & & & & & & -0.079 & & & & & \\
\hline & $(0.018)$ & & & & & & $(0.016)$ & & & & & \\
\hline \multirow[t]{2}{*}{ Native American } & 0.027 & & & & & & -0.042 & & & & & \\
\hline & $(0.046)$ & & & & & & $(0.041)$ & & & & & \\
\hline \multicolumn{13}{|c|}{ Workplace Inter-racial Interactions } \\
\hline \multirow{2}{*}{ Race Uncommon } & -0.008 & 0.002 & -0.034 & -0.007 & 0.003 & 0.094 & & & & & & \\
\hline & $(0.017)$ & $(0.040)$ & $(0.017)$ & $(0.019)$ & $(0.032)$ & $(0.064)$ & & & & & & \\
\hline \multirow[t]{2}{*}{ Race of Supervisor Different } & -0.002 & 0.000 & 0.002 & 0.000 & 0.011 & & & & & & & \\
\hline & $(0.013)$ & $(0.017)$ & $(0.022)$ & $(0.027)$ & $(0.033)$ & & & & & & & \\
\hline \multicolumn{13}{|l|}{ Civilian Opportunities Better } \\
\hline \multirow[t]{2}{*}{ Promotion } & 0.050 & 0.055 & 0.017 & 0.060 & 0.047 & -0.019 & & & & & & \\
\hline & $(0.015)$ & $(0.020)$ & $(0.023)$ & $(0.038)$ & $(0.055)$ & $(0.076)$ & & & & & & \\
\hline \multirow[t]{2}{*}{ Pay and Benefits } & 0.016 & 0.010 & 0.019 & 0.008 & 0.067 & 0.230 & & & & & & \\
\hline & $(0.012)$ & $(0.017)$ & $(0.016)$ & $(0.018)$ & $(0.033)$ & $(0.112)$ & & & & & & \\
\hline \multirow[t]{2}{*}{ Fair Performance Evaluations } & 0.038 & 0.020 & 0.065 & 0.086 & 0.048 & 0.028 & & & & & & \\
\hline & $(0.016)$ & $(0.025)$ & $(0.024)$ & $(0.032)$ & $(0.046)$ & $(0.059)$ & & & & & & \\
\hline \multirow[t]{2}{*}{ Education and Training } & 0.118 & 0.148 & 0.085 & 0.063 & 0.063 & -0.070 & & & & & & \\
\hline & $(0.018)$ & $(0.032)$ & $(0.023)$ & $(0.028)$ & $(0.034)$ & $(0.061)$ & & & & & & \\
\hline \multirow[t]{2}{*}{ Quality of Life } & & & & & & & 0.083 & 0.071 & 0.141 & 0.134 & 0.036 & 0.086 \\
\hline & & & & & & & $(0.013)$ & $(0.018)$ & $(0.023)$ & $(0.027)$ & $(0.024)$ & $(0.078)$ \\
\hline \multirow{2}{*}{$\begin{array}{r}\text { Chance to Show Pride } \\
\text { in Yourself }\end{array}$} & & & & & & & 0.122 & 0.136 & 0.088 & 0.127 & 0.035 & 0.353 \\
\hline & & & & & & & $(0.024)$ & $(0.038)$ & $(0.030)$ & $(0.039)$ & $(0.040)$ & $(0.097)$ \\
\hline \multicolumn{13}{|l|}{ Family Situation } \\
\hline \multirow[t]{2}{*}{ Married } & & & & & & & -0.049 & -0.044 & -0.030 & -0.093 & -0.018 & -0.133 \\
\hline & & & & & & & $(0.014)$ & $(0.020)$ & $(0.021)$ & $(0.027)$ & $(0.025)$ & $(0.076)$ \\
\hline \multirow[t]{2}{*}{ Presence of Children } & & & & & & & -0.039 & -0.046 & 0.000 & -0.071 & -0.089 & 0.129 \\
\hline & & & & & & & $(0.014)$ & $(0.021)$ & $(0.020)$ & $(0.025)$ & $(0.023)$ & $(0.069)$ \\
\hline
\end{tabular}

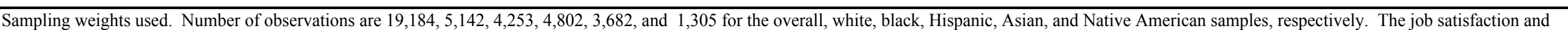

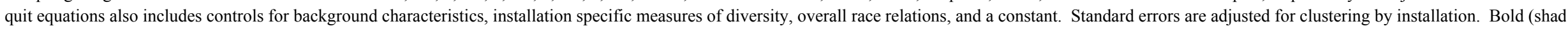
indicates significant at the 5(10) percent level. 
Table 4. The Effect of Racial Harassment on Job Dissatisfaction and Intentions to Quit the Military (Single Equation Probit Marginal Effects and Standard Errors)

\begin{tabular}{|c|c|c|c|c|c|c|c|c|c|c|c|c|}
\hline & \multicolumn{6}{|c|}{ Dissatisfaction } & \multicolumn{6}{|c|}{ Quit } \\
\hline & Overall & White & Black & Hispanic & Asian & $\begin{array}{r}\text { Native } \\
\text { American }\end{array}$ & Overall & White & Black & Hispanic & Asian & $\begin{array}{l}\text { Native } \\
\text { American }\end{array}$ \\
\hline \multirow[t]{2}{*}{ Offense } & 0.036 & 0.023 & 0.071 & 0.069 & 0.041 & 0.212 & 0.008 & 0.006 & 0.008 & 0.014 & 0.011 & 0.028 \\
\hline & $(0.011)$ & $(0.014)$ & $(0.015)$ & $(0.018)$ & $(0.025)$ & $(0.040)$ & $(0.003)$ & $(0.004)$ & $(0.003)$ & $(0.004)$ & $(0.007)$ & $(0.019)$ \\
\hline \multirow[t]{2}{*}{ Threat } & 0.082 & 0.058 & 0.106 & 0.154 & 0.038 & 0.275 & 0.019 & 0.016 & 0.012 & 0.031 & 0.010 & 0.037 \\
\hline & $(0.023)$ & $(0.030)$ & $(0.022)$ & $(0.033)$ & $(0.039)$ & $(0.107)$ & $(0.006)$ & $(0.008)$ & $(0.004)$ & $(0.009)$ & $(0.011)$ & $(0.028)$ \\
\hline \multirow[t]{2}{*}{ Career } & 0.110 & 0.117 & 0.097 & 0.099 & 0.110 & 0.211 & 0.025 & 0.032 & 0.011 & 0.020 & 0.029 & 0.028 \\
\hline & $(0.017)$ & $(0.029)$ & $(0.020)$ & $(0.028)$ & $(0.041)$ & $(0.118)$ & $(0.004)$ & $(0.008)$ & $(0.004)$ & $(0.007)$ & $(0.013)$ & $(0.024)$ \\
\hline \multirow[t]{2}{*}{ Dissatisfaction } & & & & & & & 0.227 & 0.269 & 0.110 & 0.202 & 0.267 & 0.134 \\
\hline & & & & & & & $(0.018)$ & $(0.026)$ & $(0.031)$ & $(0.034)$ & $(0.057)$ & $(0.087)$ \\
\hline
\end{tabular}

as defined in Table 3. Standard errors are adjusted for clustering by installation. Bold (shaded) indicates significant at the $5(10)$ percent level. 


\section{Offensive Encounters}

Unwelcome Attempts To Discuss Race/Ethnicity

Told Racist Stories/Jokes

Condescending Due To Race/Ethnicity

Distribute Racist Materials

Displayed Racist Tattoos/Clothing

Not Included In Activity Due To Race/Ethnicity

Uncomfortable, Hostile Looks/Stares Due to Race/Ethnicity

Offensive Remarks About Appearance Due to Race/Ethnicity

Remarks Your Race/Ethnicity Not Suited To Job

\section{Threat/Harm}

Offensive Remarks About Race/Ethnicity

Vandalized Property Due To Race/Ethnicity

Threatened With Retaliation if Did Not Partake in Racist Behavior

Physically Threatened/Intimidated Due to Race/Ethnicity

Career*

Assaulted You Physically Due to Race/Ethnicity

\section{Assignment/Career}

Assignment Has Not Made Use Of Job Skills

Current Assignment Not Good For Career

No Short Term Tasks To Prepare For Advancement

No Professional Relationship For Career Development Advice

Learned Of Opportunities Too Late For Career

No Straight Answers For Promotion Possibilities

Excluded by Peers From Social Activities

\section{Evaluation}

Rated Lower Than Deserved On Last Evaluation

Last Evaluation Contained Unjustified Comments

Held To Higher Performance Standards Than Others

Didn't Receive Award Like Others

\section{Punishment}

Wrongly Taken To Non-Judical Punishment

Punished When Others Were Not

\section{Training/Test Scores}

Unable To Attend Major School Necessary For Job

Unable To Attend Short Courses Necessary For Job

Received Lower Grades Than Deserved

Didn't Get Job Due To Scores On Test

\footnotetext{
*Coded as 1 if respondent answered yes and his/her race was a factor, zero otherwise.
} 
Appendix Table 2. Sample Means by Race

\begin{tabular}{|c|c|c|c|c|c|c|c|c|c|c|c|c|}
\hline \multirow[b]{2}{*}{ Awareness of Racial Harassment Programs } & \multicolumn{2}{|c|}{$\begin{array}{c}\text { Overall } \\
\text { Mean St. Dev. }\end{array}$} & \multicolumn{2}{|c|}{$\begin{array}{c}\text { White } \\
\text { Mean St. Dev. }\end{array}$} & \multicolumn{2}{|c|}{$\begin{array}{c}\text { Black } \\
\text { Mean St. Dev. }\end{array}$} & \multicolumn{2}{|c|}{$\begin{array}{c}\text { Hispanic } \\
\text { Mean St. Dev. }\end{array}$} & \multicolumn{2}{|c|}{$\begin{array}{c}\text { Asian } \\
\text { Mean St. Dev. }\end{array}$} & \multicolumn{2}{|c|}{$\begin{array}{l}\text { Native American } \\
\text { Mean St. Dev. }\end{array}$} \\
\hline & & & & & & & & & & & & \\
\hline Training & 0.657 & 0.475 & 0.684 & 0.465 & 0.585 & 0.493 & 0.609 & 0.488 & 0.615 & 0.487 & 0.630 & 0.483 \\
\hline Hotlines & 0.567 & 0.496 & 0.595 & 0.491 & 0.502 & 0.500 & 0.494 & 0.500 & 0.542 & 0.498 & 0.486 & 0.500 \\
\hline Channels & 0.627 & 0.484 & 0.664 & 0.472 & 0.539 & 0.499 & 0.533 & 0.499 & 0.582 & 0.493 & 0.532 & 0.499 \\
\hline \multicolumn{13}{|l|}{ Equal Opportunity Climate* } \\
\hline Racial Confrontation & 0.296 & 0.126 & 0.287 & 0.127 & 0.319 & 0.122 & 0.312 & 0.120 & 0.305 & 0.126 & 0.318 & 0.117 \\
\hline Reports of Harassment w/o Repurcussions & 0.627 & 0.096 & 0.631 & 0.097 & 0.612 & 0.092 & 0.620 & 0.091 & 0.623 & 0.091 & 0.626 & 0.096 \\
\hline Hotlines & 0.560 & 0.112 & 0.562 & 0.111 & 0.559 & 0.108 & 0.542 & 0.117 & 0.567 & 0.116 & 0.560 & 0.121 \\
\hline Channels & 0.619 & 0.113 & 0.621 & 0.113 & 0.617 & 0.110 & 0.602 & 0.116 & 0.620 & 0.118 & 0.616 & 0.113 \\
\hline Social Prescriptions* & 19.715 & 1.013 & 19.790 & 1.006 & 19.468 & 1.017 & 19.641 & 0.986 & 19.718 & 0.975 & 19.499 & 0.970 \\
\hline \multicolumn{13}{|l|}{ Workplace Inter-racial Interactions } \\
\hline Race Uncommon & 0.129 & 0.335 & 0.045 & 0.208 & 0.206 & 0.405 & 0.389 & 0.488 & 0.634 & 0.482 & 0.707 & 0.456 \\
\hline Race of Supervisor Different & 0.422 & 0.494 & 0.254 & 0.435 & 0.711 & 0.453 & 0.919 & 0.274 & 0.924 & 0.264 & 0.997 & 0.058 \\
\hline \multicolumn{13}{|l|}{ Civilian Opportunities Better } \\
\hline Promotions & 0.189 & 0.392 & 0.210 & 0.407 & 0.138 & 0.345 & 0.148 & 0.355 & 0.141 & 0.348 & 0.182 & 0.386 \\
\hline Pay and Benefits & 0.366 & 0.482 & 0.383 & 0.486 & 0.348 & 0.476 & 0.292 & 0.455 & 0.322 & 0.467 & 0.290 & 0.454 \\
\hline Fair Performance Evaluations & 0.132 & 0.338 & 0.129 & 0.335 & 0.147 & 0.354 & 0.124 & 0.330 & 0.126 & 0.332 & 0.160 & 0.367 \\
\hline Educations and Training & 0.145 & 0.352 & 0.136 & 0.343 & 0.168 & 0.374 & 0.159 & 0.366 & 0.168 & 0.374 & 0.178 & 0.382 \\
\hline Quality of Life & 0.328 & 0.470 & 0.341 & 0.474 & 0.301 & 0.459 & 0.293 & 0.455 & 0.297 & 0.457 & 0.298 & 0.458 \\
\hline Chance to Show Pride in Yourself & 0.106 & 0.308 & 0.094 & 0.292 & 0.133 & 0.340 & 0.144 & 0.351 & 0.097 & 0.295 & 0.129 & 0.335 \\
\hline \multicolumn{13}{|l|}{ Family Situation } \\
\hline Married & 0.664 & 0.472 & 0.680 & 0.466 & 0.633 & 0.482 & 0.625 & 0.484 & 0.571 & 0.495 & 0.687 & 0.464 \\
\hline Kids & 0.488 & 0.500 & 0.475 & 0.499 & 0.557 & 0.497 & 0.470 & 0.499 & 0.485 & 0.500 & 0.407 & 0.491 \\
\hline \multicolumn{13}{|l|}{ Background Characteristics } \\
\hline Male & 0.855 & 0.352 & 0.878 & 0.328 & 0.758 & 0.428 & 0.878 & 0.327 & 0.837 & 0.369 & 0.835 & 0.371 \\
\hline \multicolumn{13}{|l|}{ Education } \\
\hline High School & 0.263 & 0.440 & 0.251 & 0.433 & 0.278 & 0.448 & 0.343 & 0.475 & 0.225 & 0.418 & 0.267 & 0.443 \\
\hline Some College & 0.507 & 0.500 & 0.481 & 0.500 & 0.601 & 0.490 & 0.522 & 0.500 & 0.488 & 0.500 & 0.621 & 0.485 \\
\hline College & 0.230 & 0.421 & 0.269 & 0.443 & 0.122 & 0.327 & 0.135 & 0.342 & 0.287 & 0.452 & 0.112 & 0.315 \\
\hline \multicolumn{13}{|l|}{ Years of Active Service } \\
\hline$<6$ & 0.449 & 0.497 & 0.450 & 0.498 & 0.388 & 0.487 & 0.549 & 0.498 & 0.471 & 0.499 & 0.505 & 0.500 \\
\hline $7-11$ & 0.181 & 0.385 & 0.181 & 0.385 & 0.198 & 0.399 & 0.155 & 0.362 & 0.183 & 0.387 & 0.143 & 0.350 \\
\hline $12-19$ & 0.294 & 0.456 & 0.290 & 0.454 & 0.339 & 0.473 & 0.242 & 0.428 & 0.267 & 0.442 & 0.294 & 0.456 \\
\hline $20+$ & 0.076 & 0.264 & 0.078 & 0.269 & 0.076 & 0.264 & 0.054 & 0.227 & 0.080 & 0.271 & 0.059 & 0.235 \\
\hline Officer & 0.193 & 0.395 & 0.236 & 0.424 & 0.081 & 0.274 & 0.098 & 0.298 & 0.188 & 0.390 & 0.086 & 0.281 \\
\hline \multicolumn{13}{|l|}{ Service } \\
\hline Army & 0.344 & 0.475 & 0.305 & 0.460 & 0.488 & 0.500 & 0.379 & 0.485 & 0.276 & 0.447 & 0.410 & 0.492 \\
\hline Navy & 0.202 & 0.402 & 0.207 & 0.405 & 0.166 & 0.373 & 0.192 & 0.394 & 0.367 & 0.482 & 0.125 & 0.331 \\
\hline Marines & 0.128 & 0.334 & 0.130 & 0.336 & 0.099 & 0.299 & 0.185 & 0.388 & 0.074 & 0.262 & 0.182 & 0.386 \\
\hline Air Force & 0.325 & 0.469 & 0.359 & 0.480 & 0.246 & 0.431 & 0.243 & 0.429 & 0.282 & 0.450 & 0.283 & 0.451 \\
\hline \multicolumn{13}{|l|}{ Diversity and Overall Race-Relations* } \\
\hline Racial Relations Good & 0.664 & 0.118 & 0.674 & 0.118 & 0.633 & 0.114 & 0.651 & 0.114 & 0.659 & 0.113 & 0.649 & 0.109 \\
\hline Percent White & 0.678 & 0.112 & 0.695 & 0.107 & 0.633 & 0.114 & 0.647 & 0.109 & 0.649 & 0.117 & 0.646 & 0.110 \\
\hline
\end{tabular}

Sampling weights used. Number of observations are 19,184, 5,142, 4,253, 4,802,3,682, and 1,305 for the overall, white, black, Hispanic, Asian and Native American samples, respectively.

* indicates installation-level variables. 
Appendix Table 3. Correlation Coefficients

\begin{tabular}{|c|c|c|c|c|c|c|}
\hline & Overall & White & Black & Hispanic & Asian & $\begin{array}{r}\text { Native } \\
\text { American }\end{array}$ \\
\hline \multicolumn{7}{|l|}{ Offense/Dissatisfaction/Quit } \\
\hline $\mathrm{Rho}_{12}$ (Offense/Dissatisfaction) & $\begin{array}{r}\mathbf{- 0 . 7 5 3} \\
(0.070)\end{array}$ & $\begin{array}{r}\mathbf{- 0 . 7 3 8} \\
(0.090)\end{array}$ & $\begin{array}{r}\mathbf{- 0 . 8 3 7} \\
(0.071)\end{array}$ & $\begin{array}{r}-0.567 \\
(0.313)\end{array}$ & $\begin{array}{r}\mathbf{- 0 . 7 0 7} \\
(0.125)\end{array}$ & $\begin{array}{r}\mathbf{- 0 . 7 1 4} \\
(0220)\end{array}$ \\
\hline Rho $_{13}$ (Offense/Quit) & -0.022 & -0.029 & -0.017 & $\begin{array}{r}(0.313) \\
-0.046\end{array}$ & 0.004 & 0.179 \\
\hline & $(0.025)$ & $(0.032)$ & $(0.051)$ & $(0.057)$ & $(0.051)$ & $(0.104)$ \\
\hline $\mathrm{Rho}_{23}$ (Dissatisfaction/Quit) & $\begin{array}{r}-0.139 \\
(0.116)\end{array}$ & $\begin{array}{r}-0.107 \\
(0.157)\end{array}$ & $\begin{array}{r}-\mathbf{- 0 . 3 0 3} \\
(0.111)\end{array}$ & $\begin{array}{r}-0.097 \\
(0.210)\end{array}$ & $\begin{array}{r}-\mathbf{0 . 5 0 5} \\
(0.115)\end{array}$ & $\begin{array}{r}0.145 \\
(0.194)\end{array}$ \\
\hline $\begin{array}{l}\text { LR Test of } \mathrm{Rho}_{12}=\mathrm{Rho}_{13}=\mathrm{Rho}_{23}=0 \\
\text { P-value }\end{array}$ & 0.000 & 0.000 & 0.000 & 0.000 & 0.000 & 0.000 \\
\hline \multicolumn{7}{|l|}{ Threat/Dissatisfaction/Quit } \\
\hline Rho $_{12}$ (Threat/Dissatisfaction) & $\begin{array}{r}\mathbf{- 0 . 4 9 2} \\
(0.059)\end{array}$ & $\begin{array}{r}-0.222 \\
(0.200)\end{array}$ & $\begin{array}{r}\mathbf{- 0 . 4 2 3} \\
(0.106)\end{array}$ & $\begin{array}{r}\mathbf{- 0 . 3 4 8} \\
(0.127)\end{array}$ & $\begin{array}{r}\mathbf{- 0 . 5 9 0} \\
(0.162)\end{array}$ & $\begin{array}{r}\mathbf{- 0 . 8 6 0} \\
(0.057)\end{array}$ \\
\hline $\mathrm{Rho}_{13}$ (Threat/Quit) & 0.030 & 0.019 & 0.049 & 0.062 & 0.043 & -0.173 \\
\hline $\mathrm{Rho}_{23}$ (Dissatisfaction/Quit) & $\begin{array}{r}(0.036) \\
-0.228 \\
(0.125)\end{array}$ & $\begin{array}{r}(0.050) \\
-0.147 \\
(0.233)\end{array}$ & $\begin{array}{r}(0.043) \\
\mathbf{- 0 . 4 7 3} \\
(0.108)\end{array}$ & $\begin{array}{r}(0.060) \\
-0.184 \\
(0.231)\end{array}$ & $\begin{array}{r}(0.056) \\
\mathbf{- 0 . 6 0 6} \\
(0.147)\end{array}$ & $\begin{array}{r}(0.118) \\
0.194 \\
(0.238)\end{array}$ \\
\hline $\begin{array}{l}\text { LR Test of } \mathrm{Rho}_{12}=\mathrm{Rho}_{13}=\mathrm{Rho}_{23}=0 \\
\text { P-value }\end{array}$ & 0.000 & 0.000 & 0.000 & 0.000 & 0.000 & 0.000 \\
\hline Career/Dissatisfaction/Quit & & & & & & \\
\hline $\mathrm{Rho}_{12}$ (Career/Dissatisfaction) & $\begin{array}{r}\mathbf{- 0 . 4 7 5} \\
(0.065)\end{array}$ & $\begin{array}{r}\mathbf{- 0 . 3 8 3} \\
(0.158)\end{array}$ & $\begin{array}{r}\mathbf{- 0 . 5 7 9} \\
(0.076)\end{array}$ & $\begin{array}{r}\mathbf{- 0 . 4 9 2} \\
(0.139)\end{array}$ & $\begin{array}{r}\mathbf{- 0 . 6 4 4} \\
(0.114)\end{array}$ & $\begin{array}{r}-0.582 \\
(0.318)\end{array}$ \\
\hline $\mathrm{Rho}_{13}$ (Career/Quit) & $\begin{array}{r}0.012 \\
(0.034)\end{array}$ & $\begin{array}{r}-0.017 \\
(0.058)\end{array}$ & $\begin{array}{r}\mathbf{0 . 1 1 6} \\
(0.039)\end{array}$ & $\begin{array}{r}0.052 \\
(0.049)\end{array}$ & $\begin{array}{r}0.061 \\
(0.051)\end{array}$ & $\begin{array}{r}0.013 \\
(0.117)\end{array}$ \\
\hline $\mathrm{Rho}_{23}$ (Dissatisfaction/Quit) & $\begin{array}{r}\mathbf{- 0 . 2 9 6} \\
(0.106)\end{array}$ & $\begin{array}{r}-0.165 \\
(0.194)\end{array}$ & $\begin{array}{r}-\mathbf{- 0 . 5 2 1} \\
(0.085)\end{array}$ & $\begin{array}{r}-0.110 \\
(0.203)\end{array}$ & $\begin{array}{r}-\mathbf{0 . 5 4 3} \\
(0.127)\end{array}$ & $\begin{array}{r}0.363 \\
(0.455)\end{array}$ \\
\hline $\begin{array}{l}\text { LR Test of } \mathrm{Rho}_{12}=\mathrm{Rho}_{13}=\mathrm{Rho}_{23}=0 \\
\text { P-value }\end{array}$ & 0.000 & 0.000 & 0.000 & 0.000 & 0.000 & 0.000 \\
\hline
\end{tabular}

